\title{
IS FISCAL POLICY PROCYCLICAL IN RESOURCE-RICH COUNTRIES?
}

\author{
Ilkin Aliyev
}
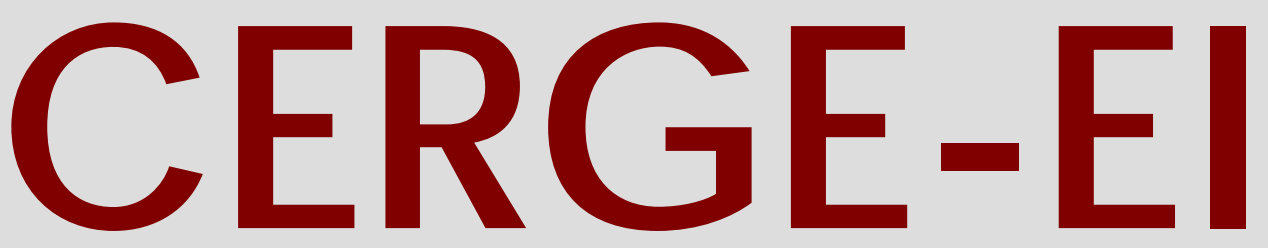

Charles University Centerfor Economic Research and Graduate Education Academy of Sciences of the Czech Republic Ec onomic s Institute 


\section{Working Paper Series $\quad 464$ (ISSN 1211-3298)}

\section{Is Fiscal Policy Procyclical in Resource-Rich Countries?}

Ilkin Aliyev

CERGE-EI

Prague, July 2012 
ISBN 978-80-7343-267-6 (Univerzita Karlova. Centrum pro ekonomický výzkum a doktorské studium)

ISBN 978-80-7344-259-0 (Národohospodářský ústav AV ČR, v.v.i.) 


\title{
IS FISCAL POLICY PROCYCLICAL \\ IN RESOURCE-RICH COUNTRIES?*
}

\author{
Ilkin Aliyev \\ CERGE-EI $^{\S}$
}

\begin{abstract}
We analyze fiscal policy procyclicality in resource-rich countries. We obtain a strong Ushaped relationship between the procyclicality of government capital expenditures and the resource richness measure comprised of the mineral exports share in total merchandise exports for developing countries. Such a relationship is robust to different methodologies and various checks. We consider two hypotheses: first, the political economy hypothesis, and second, the borrowing constraints hypothesis. Empirical observations appear to be consistent with the hypotheses. We build a model able to generate a U-shape effect combining political economy and borrowing constraint hypotheses. We argue that with a model of simple settings such a U-shape relationship can be obtained and interpreted.
\end{abstract}

Keywords: borrowing constraints, developing countries, fiscal policy, political economy, procyclicality, resource-rich

JEL Classification: E62, F34, F41, O23, Q32

*I am very grateful to Evangelia Vourvachaki and Michal Kejak for their valuable comments. I would like to thank Byeongju Jeong for his helpful comments and constant support. I also thank Laura Strakova for editing the paper and Bozena Bobkova for translating the abstract into the Czech language. All errors remaining in this text are the responsibility of the author.

${ }^{\S}$ CERGE-EI is a joint workplace of the Center for Economic Research and Graduate Education, Charles University, and the Economics Institute of the Academy of Sciences of the Czech Republic. Address: CERGEEI, P.O. Box 882, Politických vězňů 7, Prague 1, 111 21, Czech Republic, e-mail: ilkin.aliyev@cerge-ei.cz 


\begin{abstract}
Abstrakt
Tento článek se zabývá procyklicitou fiskálních politik v zemích bohatých na suroviny. Zjistili jsme, že závislost procyklicity vládních kapitálových výdajů na míre surovinového bohatství vyjádřené jako podíl exportu nerostných surovin na celkovém exportu je kvazikonvexní ve tvaru U. Tato závislost je robustní i v př́padě použití různých metodologií a jiných nemetodolgických úprav. Zabýváme se dvěma hypotézami vysvětlení tohoto vztahu: jednak hypotézou politické ekonomie a také hypotézou úvěrového omezení. Empirická pozorování se jeví jako konsistentní s těmito hypotézami. Sestavili jsme model, který umožňuje vytvořit efekt dané kvazikonvexní závislosti tvarované do U na základě hypotézy politické ekonomie a úvěrového omezení. Tvrdíme, že při použití takového modelu s jednoduchým nastavením můžeme danou kvazikonvexní do U tvarovanou závislost získat a zároveň ji interpretovat.
\end{abstract}




\section{Introduction}

Recently, more attention in the literature has been devoted to analyzing fiscal policy cyclicality. The consensus is that in developing countries fiscal policy is highly procyclical, whereas in developed countries it is less so, or is countercyclical. The key explanation for procyclical fiscal policy offered by the literature is based on political economy factors. Developed countries are equipped with strong institutions and political systems, whereas developing countries rarely have strong, healthy and stable political institutions (Gavin and Perotti 1997, Lane 2003, Kaminsky, Reinhart and Vegh 2004, Talvi and Vegh 2005)

Considering the absence of strong legal and political institutions in developing countries, Gavin and Perotti (1997), Tornell and Lane (1999) among others argue that the existence of multiple powerful groups extracting fiscal transfers would lead to a more than proportional increase of fiscal redistribution in case of favorable shocks, resulting in inefficient capital projects. Powerful groups will try to access the income to the extent they can via the fiscal process. Also, according to Alesina, Campante and Tabellini (2008), voters do not trust the corrupt government, which can appropriate tax revenues for unproductive consumption expenditures. Therefore, if the economy is booming, voters would demand immediate benefits as they believe that the government would steal it through political rents. This leads to procyclical fiscal policies. Alesina et al (2008) show that the procyclicality of fiscal policy is more pronounced in corrupt democracies where voters can hold the governments accountable.

Another commonly accepted explanation for fiscal policy procyclicality is that developing countries usually face borrowing constraints in the international financial markets (e.g. Aizenman, Gavin and Hausmann 2000, Gavin and Perotti 1997). During unfavorable times, developing countries may face tighter credit constraints which may necessitate cuts in 
their expenditures leading to procyclicality. Here, explanations based on political economy and borrowing constraints cannot be independent from each other, but they are not substitutes either. A natural question is why those credit-constrained governments do not save in favorable times, anticipating that in unfavorable times they would have to cut their expenditures significantly. To answer this question, we should consider the political and institutional environments in those countries. The procyclicality of fiscal policy is directly related to the governments' failure to save in favorable times.

The contribution of this paper is in documenting a strong non-linear U-shaped relationship between resource richness and fiscal procyclicality. In other words, up to a certain level of resource richness fiscal procyclicality declines, and afterwards it increases. Although, the literature predicts a somewhat linear relationship between resource richness and weaker political institutions, and hence higher fiscal procyclicality, we claim that resource richness can decrease fiscal procyclicality by alleviating the borrowing constraint. We argue that the two key reasons for fiscal procyclicality, namely political economy frictions and borrowing constraint, create two opposite effects in light of resource richness. This may well be the reason for the U-shaped pattern. We present empirical evidence that is consistent with the above-mentioned hypotheses. We develop a rather simple theoretical framework that addresses these hypotheses and, consequently, generates a U-shaped pattern.

In this paper, we analyze fiscal policy procyclicality in resource-rich developing economies. Resource richness may bring out and intensify the above-mentioned two types of effects on fiscal policy procyclicality. As argued in the literature, resource richness may induce rent-seeking and corrupt behavior of the government, increasing the procyclicality of the fiscal policy. Karl (1999) observes that oil exporters do not have incentives to be frugal, efficient, and cautious in policymaking. Access to easy money weakens institutions and 
decreases fiscal discipline. In the case of resource abundance the common pool problem becomes more severe and fighting over resources intensifies, as argued in Alesina, Campante and Tabellini (2008). The governments of resource-rich countries may come under constant political pressure to spend revenues as a result of raising resource prices. In the case of lower resource prices, maintaining such high levels of government spending may not be possible, leading to significant cuts. Eifert, Gelb and Tallroth (2003) discuss how different political systems can lead to different fiscal policy behaviors in resource-rich countries. As they argue, mature democracies or reformist autocracies are better able to smooth the government expenditures across cycles and thus run a less procyclical fiscal policy, whereas other political systems create obstacles in running stable fiscal policies.

On the contrary, discoveries of natural resources can be considered a windfall to governments, because the resource sector is usually owned by the government. Such ownership would provide extra "fiscal space" to governments, that they can use to finance their expenditures. In such a case, to increase public spending today the government need not decrease spending in the future. The government would have an additional opportunity to save in "good times" and therefore to pursue a less procyclical fiscal policies in "bad times". Many resource-rich countries could build vast international reserves from their resource revenues. Owning significant reserves may help governments to decrease expenditures less in case of negative shocks to the economy by alleviating the borrowing constraint. In light of this, Zhou (2009) argues that in the developing countries political risk, cyclicality of fiscal policies, and level of international reserves are strongly related to each other. Moreover, even the "least" creditworthy resource-rich countries are able to cash their natural resources. For 
example, despite being assigned very low credit ratings, Bolivia, Venezuela and Iran could export their oil and gas resources as there was a global demand. ${ }^{1}$

The paper is organized as follows: the next section discusses procyclicality in resourcerich countries, documents the key observations, and lays the basis for the main hypotheses. In Section 3, we provide important empirical evidence that is consistent with our story and hypotheses. Section 4 builds the model that incorporates these hypotheses and discusses the model-driven results. Section 5 concludes.

\section{Fiscal procyclicality in resource-rich countries}

First of all, a relevant measure should be defined to analyze fiscal policy cyclicality, as it is not readily available and needs to be estimated. Such a cyclicality measure could be estimated using different fiscal aggregates such as primary fiscal balance, government expenditures, or tax revenues, and using different estimation methodologies. As argued in Kaminsky et al (2004), the most suitable fiscal variable for fiscal policy cyclicality analysis is government expenditures. Here, we will employ this approach to make our results and discussion comparable with those of the earlier studies, and use total government expenditures and its components for our analysis. ${ }^{2}$

To obtain the cyclicality measure we run the following regression between the growth of real government expenditures and real GDP growth, similar to Woo (2009).

$$
\ln G_{i t}-\ln G_{i t-1}=\delta_{i}+\beta_{i}\left[\ln Y_{i t}-\ln Y_{i t-1}\right]+\varepsilon_{i t}
$$

\footnotetext{
${ }^{1}$ As of September 2009, Moody's assigned a very low credit rating B2 to the governments of Venezuela and Bolivia for their foreign currency bonds. Iran was not assessed.

${ }^{2}$ See appendix A for a detailed description
} 
Along with the cyclicality measure for real total government expenditures (beta_rtote), we obtain cyclicality measures for real government current (beta_rcure) and capital expenditures (beta_rcape). Summary of obtained cyclicality measures $-\beta$ 's, is reported in Table 1 below. Although we started with 170 countries, due to data limitations we could obtain cyclicality measures for only 99 countries. For some countries, there are just 4 years of observations during the 1970-2007 period. As a low number of observations leads to larger errors in obtained cyclicality measures, for some countries the measure may not be representative. Therefore, to get a more reliable measure we decided to use only the sample of countries which has at least 20 years of observations. Applying such a filtering reduces the number of countries to 61 .

Table 1: Averages of betas obtained through (1), for countries that have at least 20 years of government expenditure data

\begin{tabular}{|l|c|c|c|c|}
\hline & beta_rtote & beta_rcure & beta_rcape & $\begin{array}{c}\text { Growth volatility } \\
\mathbf{1 9 6 0 - 2 0 0 3}\end{array}$ \\
\hline All countries & 0,526 & 0,402 & 1,390 & 1,798 \\
\hline OECD & $-0,038$ & $-0,063$ & 0,367 & 1,122 \\
\hline Non-OECD & 0,868 & 0,678 & 2,051 & 2,089 \\
\hline Group 1: Resource-poor non-OECD & 0,968 & 0,849 & 2,288 & 1,834 \\
\hline Group 2: Resource-rich ${ }^{1)}$ non-OECD & 0,713 & 0,490 & 1,752 & 2,519 \\
\hline Group 3: Resource-rich ${ }^{1)}$ OECD & 0,429 & 0,350 & 1,289 & 0,993 \\
\hline Group 4: Resource-poor OECD & $-0,136$ & $-0,154$ & 0,162 & 1,143 \\
\hline
\end{tabular}

1) The country is considered to be resource-rich if the average mineral exports share in total merchandise exports during 1961-2000 is higher than 20 percent, otherwise resource-poor.

From Table 1 we see that, consistent with the existing literature, government expenditures for non-OECD countries are on average more procyclical whereas for OECD countries they are less procyclical, and even countercyclical. This result holds not only for total expenditures, but also for current and capital expenditures. Also, for all country groups - 
both OECD and non-OECD countries - the capital expenditures are more procyclical than current expenditures. The same applies for resource-rich and resource-poor countries as well. This is not surprising, as the real business cycles literature documents much higher volatility for capital expenditures than for current expenditures.

Within the resource-rich group, resource-rich non-OECD countries have higher procyclicality than resource-rich OECD countries. Non-OECD countries have weaker institutions than do OECD countries. As argued in the literature, resource richness creates enormous financial wealth that may foster corruption and rent seeking. This is consistent with the political economy story in the literature, which argues that the developing countries with weak institutions may suffer more with more resource richness. Karl (1999) discusses the political problems facing the oil-producing countries, namely low fiscal discipline, rent seeking, and corruption, due to the access to easy money by the political authority. Leaders of oil-producing countries do not have to be efficient and cautious in policymaking. Eifert, Gelb and Tallroth (2003) describe the autocratic regimes in different oil-exporting countries that fail to save enough during booms and therefore run procyclical fiscal policies.

The statistics in Table 1 for resource-rich and poor country groups within OECD and non-OECD countries gives an even more interesting picture. Within OECD, for the resourcerich countries the government's total expenditures and its components are more procyclical than for resource-poor countries. However, for non-OECD, the opposite is true. In other words, for resource-rich developing countries the government expenditures are less procyclical than for resource-poor developing countries. This implies that resource richness facilitates different types of fiscal behavior for OECD and non-OECD countries' governments. This result is somewhat surprising, as the literature implicitly predicts a more procyclical fiscal policy with more resource abundance due to the common pool problem. 
Even if the common pool problem exists, this result suggests that there may exist another effect that decreases procyclicality with resource richness.

Here, to explain the observation that resource-rich developing countries may run less procyclical fiscal policies than resource-poor developing countries, the borrowing constraint alleviation story is more plausible. This mechanism suggests that if a country is not facing a credit constraint it can borrow during unfavorable shocks so as not to decrease government expenditures with the business cycle, and therefore run a less procyclical or countercyclical fiscal policy ${ }^{3}$. Consequently, if a country is constrained the procyclical fiscal policy is more likely. Governments that own mineral resources and the foreign exchange stemming from it should be able to finance the expenditures. Also, many resource-rich countries have built vast international reserves from resource exports. From an international investor perspective, governments that own huge wealth become less likely to default, which it increases the investors' willingness to lend. It might be true for the developing countries that as the country become richer in mineral resources it will face a less tight borrowing constraint.

In order to build our political economy and borrowing constraint stories, we make two crucial assumptions. First, we assume that OECD countries face less tight or no borrowing constraints, whereas non-OECD countries do. The second assumption is that unlike nonOECD countries, OECD countries have strong institutions that can effectively limit rentseeking and corruption.

\footnotetext{
${ }^{3}$ Here, it is assumed that it is optimal to run countercyclical or acyclical fiscal policies. Although, the countercyclical fiscal policy is preferred, Perotti (2007) summarizes situations when a procyclical fiscal policy can be optimal. Such optimality mainly assumes the distortionary role of the government for the private sector of the economy.
} 
Of further importance is that the political economy situation and the government's borrowing constraints are strongly related to each other. Arguably, a government that is rent seeking and corrupt is likely to face a tighter borrowing constraint. If the institutional environment is unable to control corruption or rent seeking, then resource richness can lead to even tighter borrowing constraints, in contrast to the borrowing constraint alleviation described above. However, the borrowing constraint alleviation story in our hypothesis can be understood as a "wealth" effect with resource ownership. In other words, resource-rich governments possess significant resource wealth that increases their fiscal sustainability which in turn helps to alleviate the borrowing constraint.

Given that there are at least two effects, as stated in our hypotheses, stemming from resource ownership in the developing countries, we would expect a non-linear or nonmonotonous relationship between procyclicality and resource richness, whereas for OECD countries the relationship is expected to be different and possibly non-existent. Below, Figure 1 to Figure 3 show a direct relationship between fiscal policy cyclicality and resource richness. As a resource richness measure we use mineral exports share in total merchandise exports between 1961 and 2000 (min6100) taken from WDI. ${ }^{4}$

\footnotetext{
${ }^{4}$ Appendix A contains a more detailed data description.
} 
Figure 1: Governments' total expenditures cyclicality in non-OECD countries for countries that have at least 20 years of government expenditure data

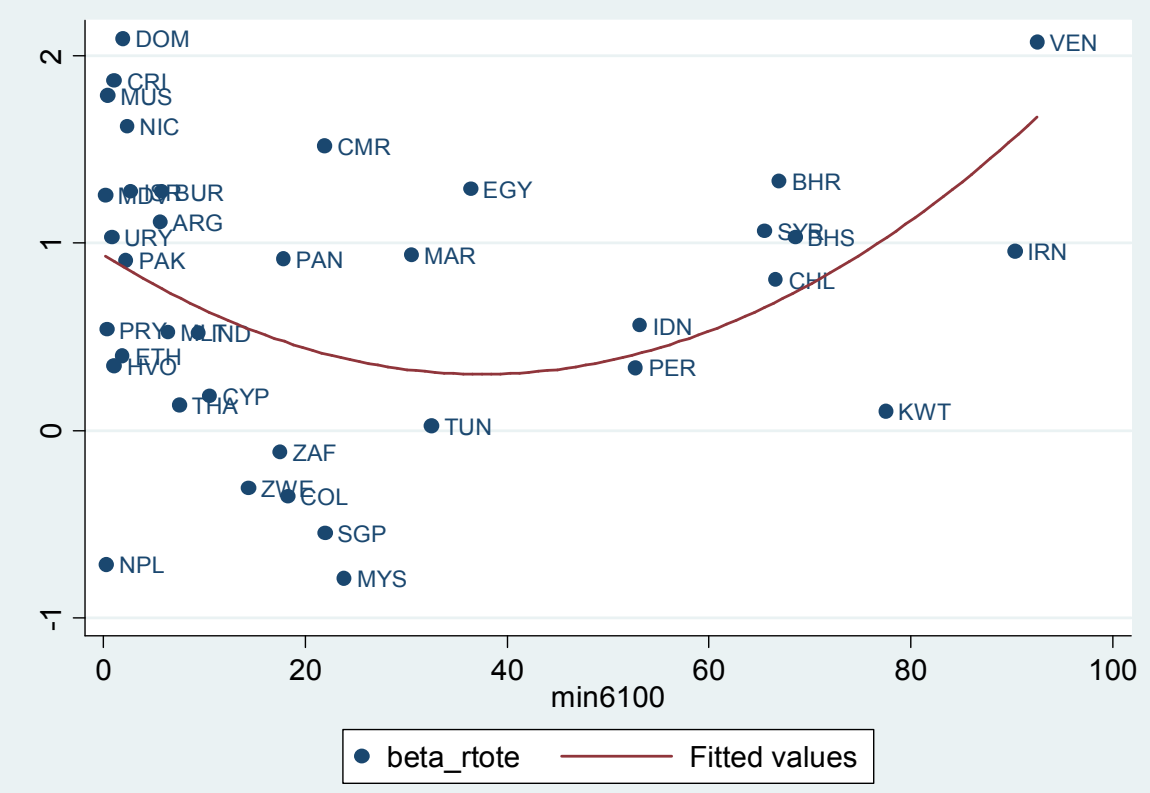

Figure 2: Governments' current expenditures cyclicality in non-OECD countries for countries that have at least 20 years of government expenditure data

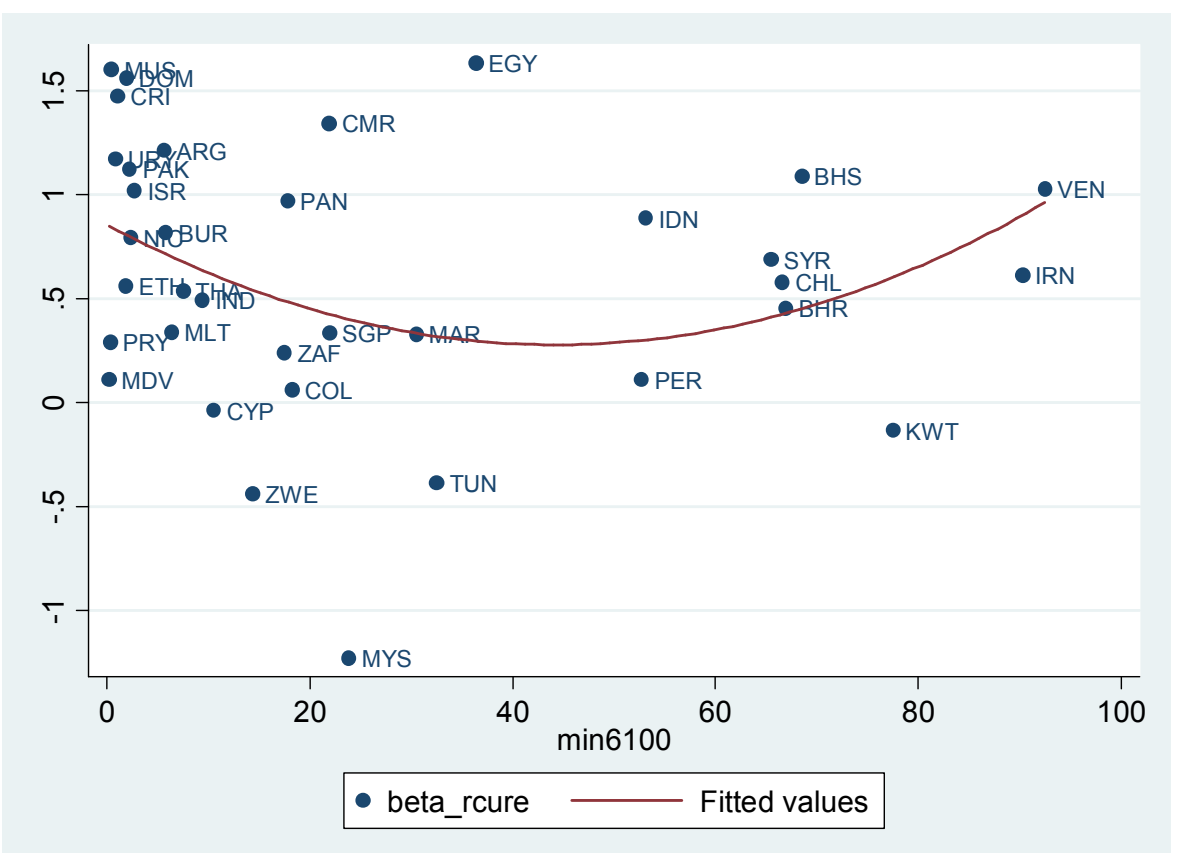


Figure 3: Governments' capital expenditures cyclicality in non-OECD countries for countries that have at least 20 years of government expenditure data

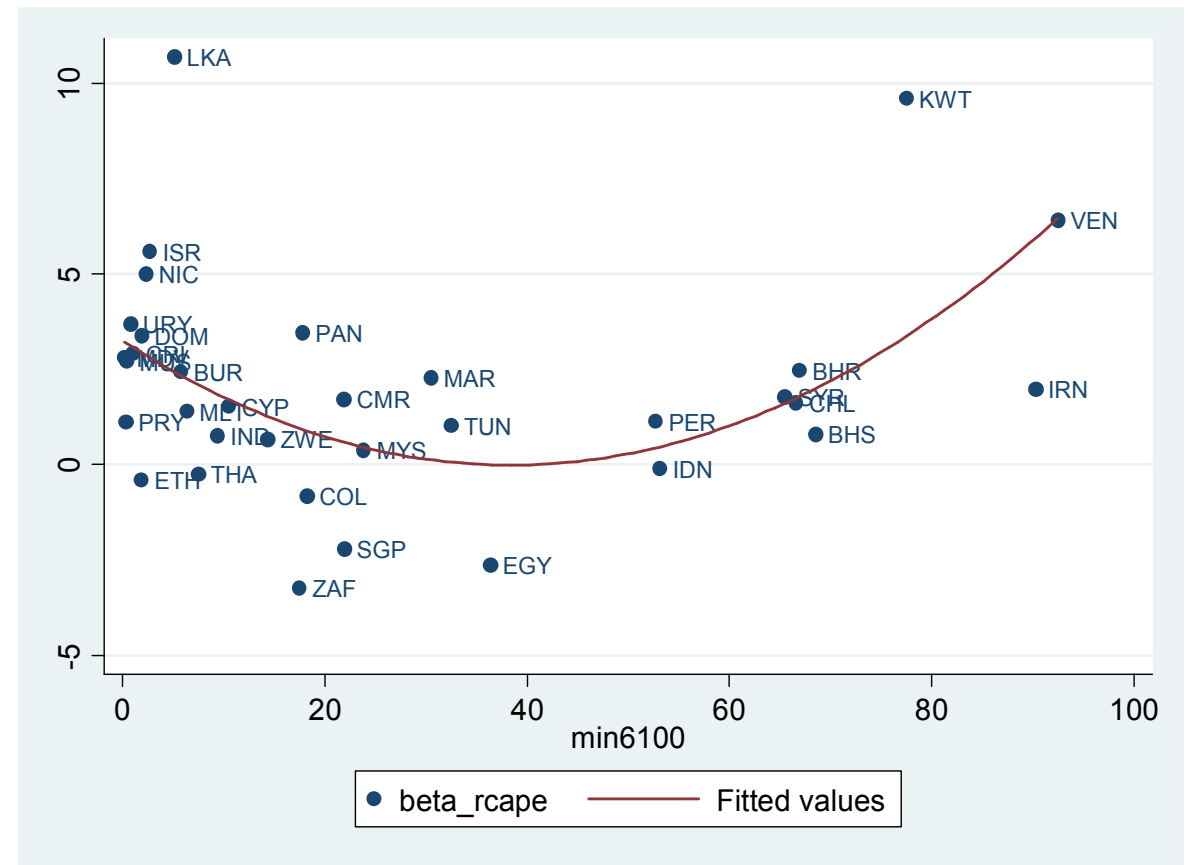

Interesting patterns emerge. In Figure 1, we observe a somewhat U-shaped pattern in the betas for total government expenditures with respect to resource richness. In Figure 2, there is no clear pattern for current expenditures cyclicality. However, Figure 3 suggests that there is a clear U-shaped relationship between resource richness and capital expenditure cyclicality in non-OECD countries.

To check the statistical significance of the U-shaped pattern, Table 2 below reports the simple regression relationship between fiscal procyclicality and the resource richness measure with its squared term. From the table it can be seen that resource richness alone does not explain the cross-country differences in fiscal cyclicality. Interestingly, inclusion of the squared term of resource richness variable changes the picture significantly; both the resource richness and its squared term become statistically significant. This is especially true for the betas of capital expenditures, though the betas for current expenditures also exhibit some level of statistical significance. This confirms that procyclical current expenditures can create 
more political pressure; thus governments prefer to smooth the current expenditures along the business cycles more than capital expenditures. Possibly, the capital expenditures are of a more discretionary nature.

Table 2: OLS regressions - Government expenditures procyclicality measures vs. resource richness, for nonOECD countries that have at least 20 years of government expenditure data

\begin{tabular}{|c|c|c|c|c|c|c|}
\hline & \multicolumn{2}{|c|}{ beta_rtote } & \multicolumn{2}{|c|}{ beta_rcure } & \multicolumn{2}{|c|}{ beta_rcape } \\
\hline MIN6100 & $\begin{array}{l}-0,0017 \\
(-0,25)\end{array}$ & $\begin{array}{l}-0,0415 \\
(-1,81)^{*}\end{array}$ & $\begin{array}{l}-0,0042 \\
(-0,84)\end{array}$ & $\begin{array}{l}-0,0261 \\
(-1,50)\end{array}$ & $\begin{array}{l}0,0094 \\
(0,53)\end{array}$ & $\begin{array}{c}-0,1651 \\
(-3,03)^{* * *}\end{array}$ \\
\hline MIN6100_2 & - & $\begin{array}{l}0,0005 \\
(1,81)^{*}\end{array}$ & - & $\begin{array}{l}0,0003 \\
(1,32)\end{array}$ & - & $\begin{array}{c}0,0022 \\
(3,34)^{* * * *}\end{array}$ \\
\hline $\begin{array}{l}\text { Adjusted } \\
\text { R_squared }\end{array}$ & 0,00 & 0,03 & 0,00 & 0,01 & 0,00 & 0,22 \\
\hline \# of obs & 38 & 38 & 37 & 37 & 35 & 35 \\
\hline
\end{tabular}

t-stats are in the brackets under coefficients. Variables MIN6100 - fuels and ores and metals exports share in total merchandise exports, MIN6100 2 - the square of min6100.

We also perform a robustness check for the estimation of our procyclicality measures. Specifically, as an alternative to the main method, we estimate the procyclicality measure as the correlation between the cyclical components of GDP and government expenditures. Having done so, we confirm the U-type relationship between procyclicality and resource richness. Appendix B provides further details.

We also check whether such a U-shaped relationship persists if we use alternative measures of resource richness. For that, we turn to three additional measures used in the literature: the share of primary products in GNP; the share of mineral production in GNP (borrowed from Sachs and Warner 1997); and the fraction of GDP produced in the Mining and Quarrying sector borrowed from (Sala-i-Martin et al 2004). Detailed description of data can be found in the Appendix A. Table 3 below checks the existence of U-shaped dependence between capital expenditure procyclicality and those resource richness measures. 
Table 3: OLS regressions - Government capital expenditures procyclicality measures vs. alternative resource richness measures, for non-OECD countries that have at least 20 years of government expenditure data

\begin{tabular}{|c|c|c|c|c|c|c|c|c|}
\hline & \multicolumn{8}{|c|}{ Dependent variable: government capital expenditures procyclicality - beta_rcape } \\
\hline & (1) & (2) & (3) & (4) & $(5)$ & (6) & $(7)$ & $(8)$ \\
\hline SXP & $\begin{array}{c}0,0941^{* *} \\
(2,70)\end{array}$ & $\begin{array}{l}0,0197 \\
(0,19)\end{array}$ & - & - & - & - & - & - \\
\hline SXP_2 & - & $\begin{array}{l}0,0011 \\
(0,79)\end{array}$ & - & - & - & - & - & - \\
\hline SXP80 & - & - & $\begin{array}{c}0,1023^{* *} \\
(2,66)\end{array}$ & $\begin{array}{l}0,0351 \\
(0,33)\end{array}$ & - & - & - & - \\
\hline SXP80_2 & - & - & - & $\begin{array}{l}0,0011 \\
(0,67)\end{array}$ & - & - & - & - \\
\hline SNR & - & - & - & - & $\begin{array}{c}0,0690^{*} \\
(1,94)\end{array}$ & $\begin{array}{l}-0,1755 \\
(1,81)^{*}\end{array}$ & - & - \\
\hline SNR_2 & - & - & - & - & - & $\begin{array}{c}0,0046 \\
(2,79)^{* *}\end{array}$ & - & - \\
\hline MINING & - & - & - & - & - & - & $\begin{array}{l}0,1027 \\
(1,30)\end{array}$ & $\begin{array}{l}-0,3173 \\
(1,82)^{*}\end{array}$ \\
\hline MINING_2 & - & - & - & - & - & - & - & $\begin{array}{l}0,0175 \\
(2,65)^{* *}\end{array}$ \\
\hline $\begin{array}{l}\text { Adjusted } \\
\text { R_squared }\end{array}$ & 0.16 & 0.15 & 0.17 & 0.15 & 0.08 & 0.23 & 0.02 & 0.18 \\
\hline \# of obs & 33 & 33 & 31 & 31 & 33 & 33 & 33 & 33 \\
\hline
\end{tabular}

Regression (3) excludes BHS and BHR which has extremely high SXP80, more than $100 \%$ and $300 \%$ respectively.

The results in columns (2) and (4) show that there is no U-shaped pattern for the share of exports of primary products in GNP (SXP and SXP80). Instead, there is a strong positive linear dependence as shown in columns (1) and (3). On the other hand, columns (6) and (8) exhibit a statistically significant U-shaped relationship for the share of mineral production in GDP (SNR) and for the fraction of GDP produced in the Mining and Quarrying sector (MINING). 
In order to interpret the differences in results, it is important to understand the differences in the measures of resource abundance. In general, we have considered two categories of resource abundance measures based on: 1) primary products (like SXP and SXP80); and 2) mineral products (like SNR, MINING and MIN6100). Mineral products are perceived to be exhaustible; primary products include both exhaustible and non-exhaustible resources. We claim that these differences originate from the nature of the resource abundance measures. According to the Standard International Trade Classification, primary products are broader than mineral products, the latter including: Food and live animals (SITC 0), Beverages and tobacco (SITC 1), Crude materials, inedible, except fuels (SITC 2), Mineral fuels, lubricants and related materials (SITC 3), Animal and vegetable oils and fats (SITC 4) and Non-ferrous metals (SITC 68). Such mineral goods may have a different ownership structure than non-mineral primary goods. Mineral resources are mainly owned by national governments or by state enterprises. This fact translates into significant export earnings from resources accruing into the government account, whereas earnings from nonmineral resources exports, such as agricultural products, are collected partially through taxes. Therefore, these two categories of resources may have different fiscal implications (Aliyev 2011).

\section{Empirical observations}

To summarize the hypotheses described in the previous section, for non-OECD countries with mineral resource ownership two effects kick in for fiscal policy procyclicality: 1) political economy problems, like rent seeking and corruption; 2) credit constraint alleviation. In this section, we provide empirical support for those hypotheses. 


\subsection{Resource richness and institutions}

We now turn our attention to the first hypothesis, namely the existence of a positive relationship between resource richness and political economy problems like rent-seeking, corruption, and government ineffectiveness. As found in the literature, we would expect resource richness to induce rent seeking and corrupt behavior by the government. In other words, we check whether there exist a direct relationship between resources, control of corruption, and the government's effectiveness measures. Table 4 serves that purpose.

Table 4: OLS regressions - Control of Corruption and Government Effectiveness

vs. resource richness, non-OECD countries

\begin{tabular}{|l|c|c|c|c|}
\hline & $\begin{array}{c}\text { Control of } \\
\text { corruption }\end{array}$ & $\begin{array}{c}\text { Government } \\
\text { effectiveness }\end{array}$ & $\begin{array}{c}\text { Voice and } \\
\text { accountability }\end{array}$ & $\begin{array}{c}\text { Political } \\
\text { stability }\end{array}$ \\
\hline min6100 & $\begin{array}{c}-0,0081 \\
(-3,10)^{* * *}\end{array}$ & $\begin{array}{c}-0,0069 \\
(-2,76)^{* * *}\end{array}$ & $\begin{array}{c}-0,0096 \\
(-3,65)^{* * *}\end{array}$ & $\begin{array}{c}-0,0073 \\
(-2,32)^{* *}\end{array}$ \\
\hline lgdpea70 & $\begin{array}{c}0,5575 \\
(5,71)^{* * *}\end{array}$ & $\begin{array}{c}0,5631 \\
(6,07)^{* * *}\end{array}$ & $\begin{array}{c}0,5022 \\
(5,21)^{* * *}\end{array}$ & $\begin{array}{c}0,4717 \\
(4,10)^{* * *}\end{array}$ \\
\hline Adjusted & 0,285 & 0,279 & 0,243 & 0,148 \\
\hline \#-squared & 82 & 93 & 94 & 94 \\
\hline \#-stats are in the brackets under coefficients.
\end{tabular}

The regression columns in Table 4 indicate that resource richness is significant to explaining corruption and government effectiveness. We include initial per capita income (log of per capita GDP in 1970) as an additional control variable. In the high income countries, control of corruption and government effectiveness would be high, and therefore, create bias in the estimation. The coefficients are highly statistically significant and have the expected sign. In this case, the results tell us that resource richness decreases control of corruption, government effectiveness, voice and accountability, and political stability, as was expected. 
Mostly, rich countries have strong political and economic institutions in place. They are characterized by clear property rights, high control of corruption, contained rent seeking, and effective government. Generally, government investments are complements, not substitutes, for private investments. Under these circumstances, such governments pursue long-horizon policies which help them efficiently use resource revenues. OECD countries are considered to be rich and mature democracies. But, there do exist a few rich non-OECD countries with strong institutions, e.g. Singapore and Chile. These countries enjoy a high level of transparency in their political systems, enabling them to run effective economic and fiscal policies.

Below, Figure 4 and Figure 5 visualize the negative relationship between political economy variables and resource richness for the poorer non-OECD countries, i.e. those that had lower GDP per capita in 1970 than the average OECD measure.

Figure 4: Control of corruption during 1996-2008 vs. resource richness measure MIN6100: for resource-rich non-OECD countries that have per capita GDP lower than average OECD in 1970

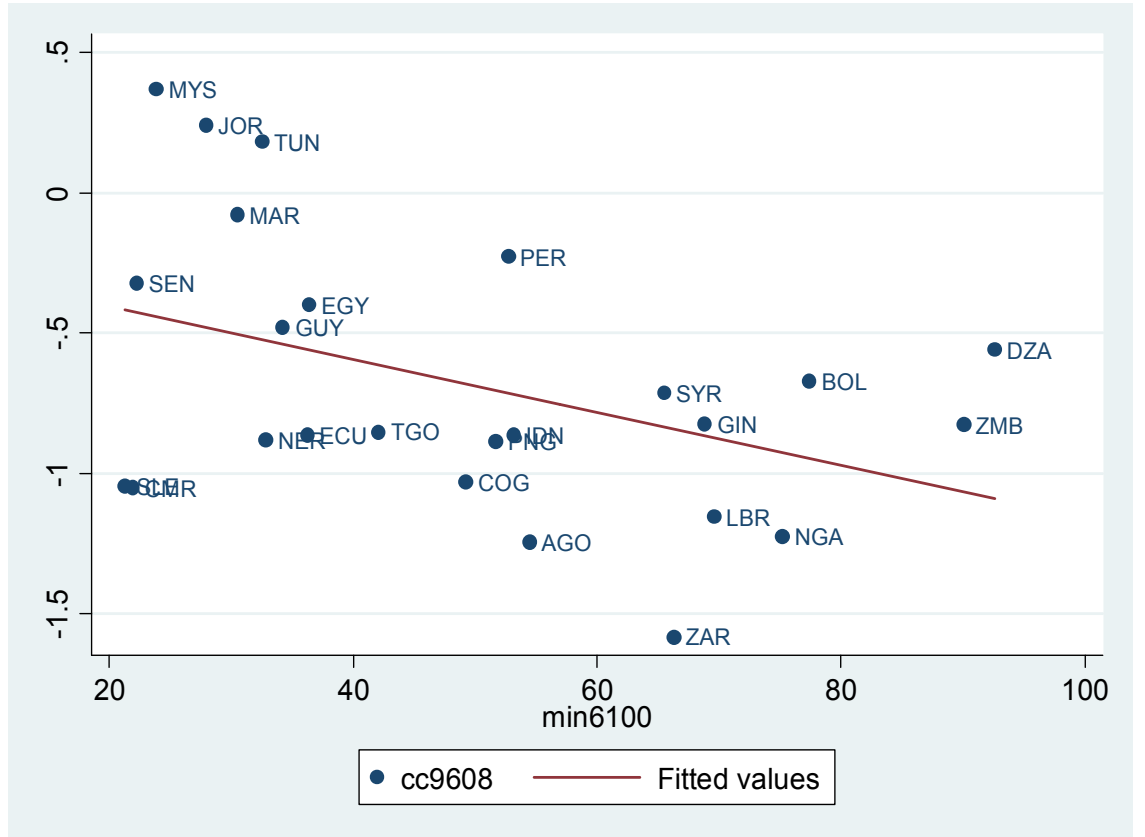


Figure 5: Government effectiveness during 1996-2008 vs. resource richness measure MIN6100: for resource-rich non-OECD countries that have per capita GDP lower than average OECD in 1970

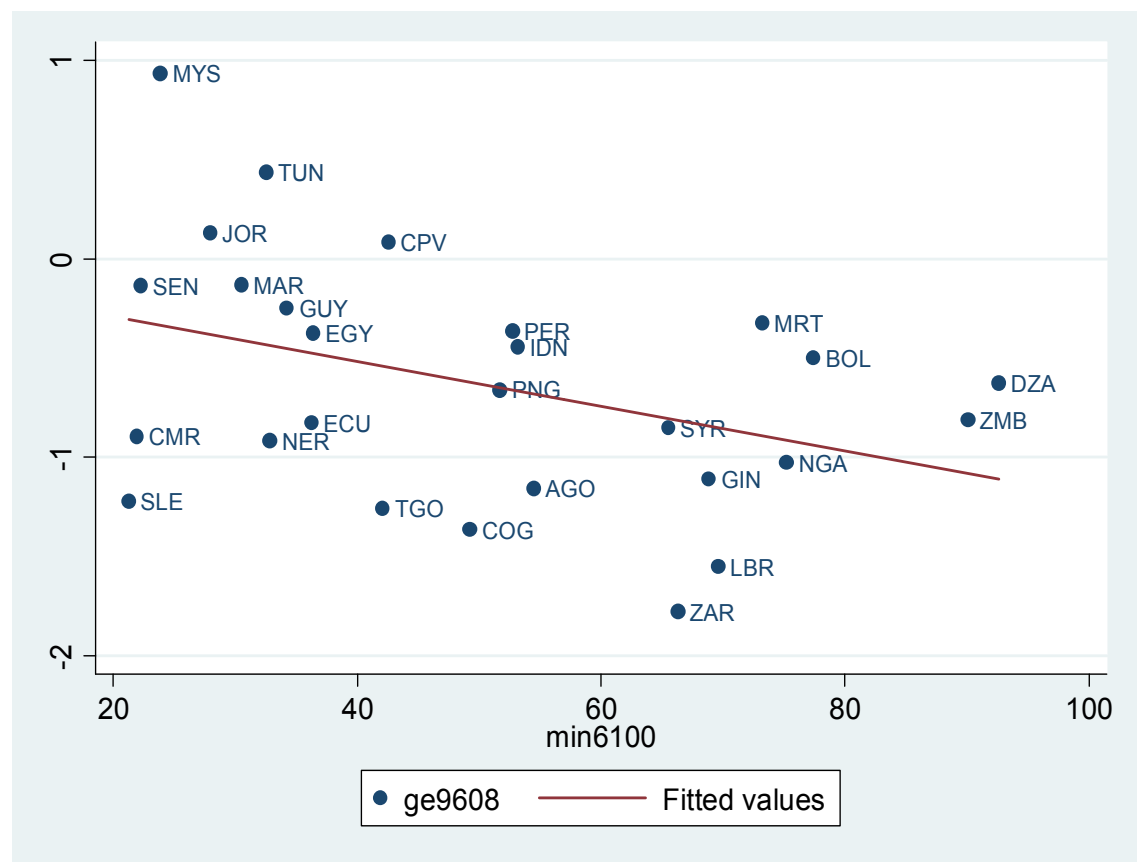

In general, commodity shocks, either of price or production nature, often can be very large, leading to very large swings in growth and government revenues. In order to avoid a highly procyclical fiscal policy such shocks may necessitate running large fiscal surplus or deficits. This may not always be possible. If the government is not credible and trustworthy, it cannot successfully defend the position of running large surpluses during favorable times and hence increases its expenditures to keep the public appeased. But then in unfavorable times, if it cannot borrow, it must cut its expenditures significantly.

\subsection{Resource richness and borrowing constraint}

In this section we look at the credit constraint alleviation hypothesis. First, we need to have a measure for credit constraint. Here, we use Foreign-Currency Government Bond Ratings issued by Moody's Investors Service, as such a measure "reflects the government's capacity and willingness to mobilize foreign exchange to repay its foreign-currency denominated 
bonds on a timely basis" (Moody's Investors Service 2006). These ratings are not published numerically, so we assign numerical values to the issued ratings between 1 and 19, with 1 representing the least constrained governments. We then look at the relationship between the mineral export share and government bond ratings issued by Moody's, shown in Table 5.

Table 5: OLS regressions - Government bond ratings vs. resource richness, non-OECD countries

\begin{tabular}{|c|c|c|c|c|c|}
\hline & \multicolumn{5}{|c|}{ Dependent variable: Foreign-Currency Government Bond Ratings issued by Moody’s in September 2009} \\
\hline $\min 6100$ & $\begin{array}{c}-0,0385^{*} \\
(-1,75)\end{array}$ & $\begin{array}{c}-0,0254^{*} \\
(-1,95)\end{array}$ & $\begin{array}{c}-0,0417 * * * \\
(-3,57)\end{array}$ & $\begin{array}{c}-0,0330^{*} \\
(-1,99)\end{array}$ & $\begin{array}{c}-0,0391 * * \\
(-2,68)\end{array}$ \\
\hline $\operatorname{cc} 9608$ & - & $\begin{array}{c}-4,705 * * * \\
(-9,58)\end{array}$ & - & $\begin{array}{c}-5,0684 * * * \\
(-8,76)\end{array}$ & - \\
\hline ge9608 & - & - & $\begin{array}{c}-5,5443 * * * \\
(-11,17)\end{array}$ & - & $\begin{array}{c}-5,7557 * * * \\
(-10,63)\end{array}$ \\
\hline lgdpea70 & - & - & - & $\begin{array}{c}1,3539^{*} \\
(1,76)\end{array}$ & $\begin{array}{l}1,0026 \\
(1,54)\end{array}$ \\
\hline Adjusted R-squared & 0,04 & 0,66 & 0,72 & 0,66 & 0,73 \\
\hline \# of observations & 57 & 51 & 53 & 42 & 43 \\
\hline
\end{tabular}

t-stats are in the brackets under coefficients.

The table shows that the coefficient is negative and significant at conventional levels, meaning that more resource richness is associated with more positive bond ratings. As expected, bond ratings, i.e., borrowing constraint, are determined by many other important factors. An undeniable factor is the institutional and political economic situation of the country, which should be included as a control. From this we surmise that institutional development might be dominating resource richness in the determination of the ratings. For example, though Venezuela is very resource rich, it also has poorly-developed institutions which are probably a key determinant of the very low assigned bond ratings.

Inclusion of the institutional development measure, such as control of corruption or government effectiveness, improves the significance of resource richness on bond ratings. 
Figure 6 below shows how the ratings differ with resource richness for non-OECD countries; the relationship is negative. In this graph, we select only those countries that have at least some level of institutional development (i.e., $c c 9608>0$ ) in order not to "lose" the visualization of the correlation between bond ratings and resource richness.

Figure 6: Foreign currency government bond ratings by Moody's as of September 2009 vs. resource richness measure $\min 6100$ : Non-OECD countries that have "some" control of corruption $(\operatorname{cc} 9608>0)$

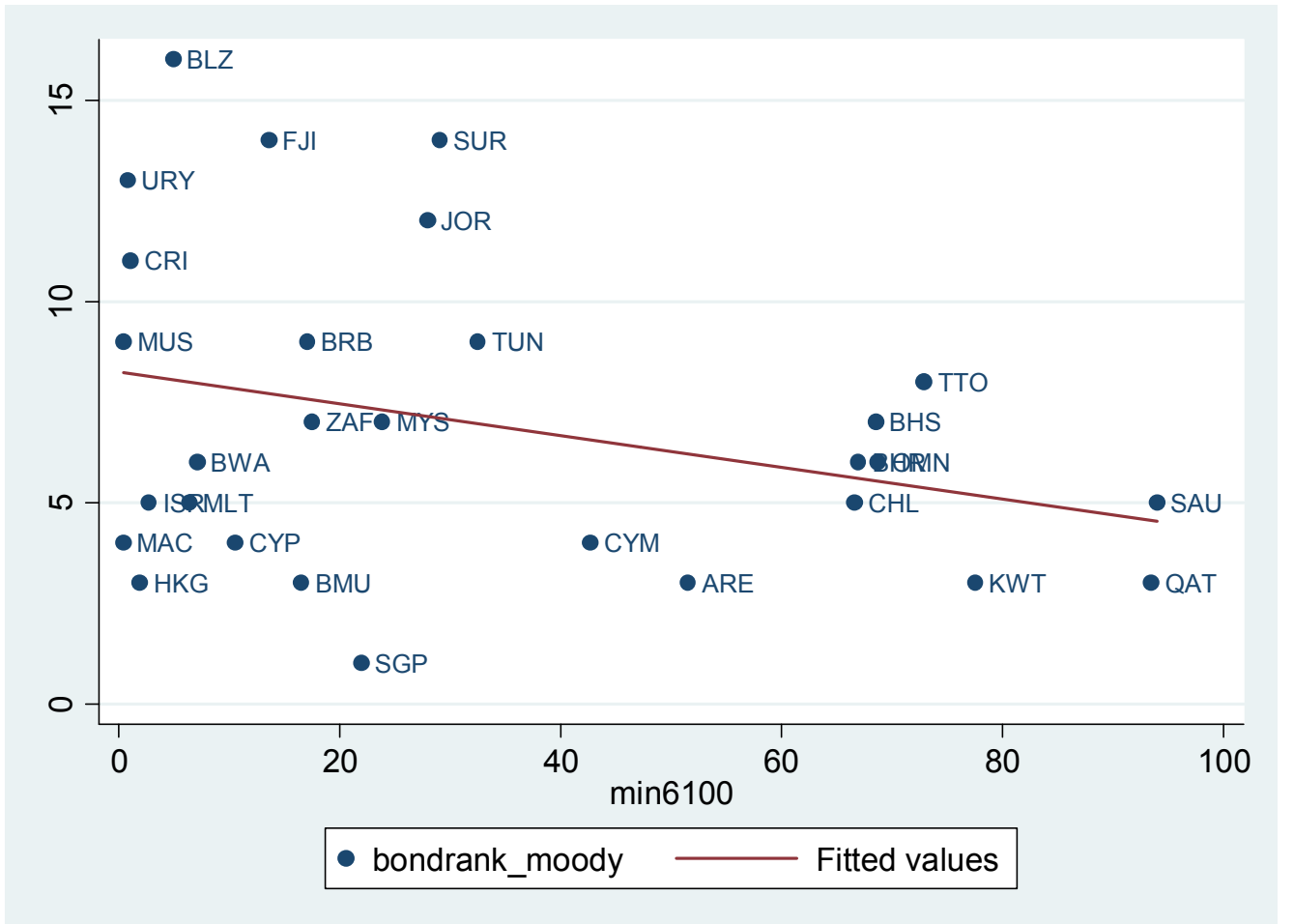

\section{Theoretical framework}

In this section, we build a highly stylized theoretical model that incorporates the two hypotheses developed in the previous sections into one framework. Under these two settings, we are able to obtain a U-shaped relationship between the procyclicality of government consumption and resource richness. Although the most significant U-shaped pattern is obtained with capital expenditures, as argued in the literature, those expenditures are actually consumption expenditures. For example, Talvi and Vegh (2005) claim that the public 
investments associated with commodity booms should be viewed as government consumption as those non-productive investments fail to generate future consumption.

We consider a two-period social planner model. The government receives revenues from the resource sector $Z$ as endowment and from the stable non-resource sector $T$ as tax collections, and it can borrow $B$. The initial period budget constraint is:

$$
C_{0}=Z_{0}+T+B
$$

In the last period, to finance consumption $C_{1}$ it receives unchanged tax income $T$ and resource income $Z_{1}$, and it has to fully repay its debt. Moreover, the government of the developing country faces a borrowing constraint in the international marketplace. To formalize the idea of credit constraint faced by governments when borrowing, we adopt the following representation that the higher the debt amount, the more interest it requires:

$$
C_{1}=Z_{1}+T-R\left(\frac{B}{\bar{Z}}\right) B
$$

Here, $R\left(\frac{B}{\bar{Z}}\right)$ is the interest rate, and it is an increasing convex function, $R^{\prime}(\cdot)>0$ and $R^{\prime \prime}(\cdot)>0$. Such a formalization implies limits on borrowing as the cost of serving the debt increases rapidly. $\bar{Z}$ is the long-term average resource income describing the resource the wealth of the country. The motivation behind such a formulation is to capture wealth effect arising from resource ownership. In other words, if the government owns higher resource 
wealth then the sustainability of its debt becomes stronger, and hence, it decreases the interest rate by playing a collateral role. ${ }^{5}$

The government maximizes 2-period utility by choosing the consumption in periods 0 and 1 , and the borrowing in period 0 . The aggregate utility function is given by:

$U\left(C_{0}\right)+U\left(C_{1}\right)-f\left(\frac{P S_{0}}{T}\right) U(\bar{C})$

Here, $\bar{C}$ is the long-term average of consumption. In this formulation, the government's primary budget balance $P S_{0}$ enters into the utility through increasing convex function $f, f(0)=0, f^{\prime}(\cdot)>0$ and $f^{\prime \prime}(\cdot)>0$. Formally, primary surplus is represented as:

$$
P S_{0}=T+Z_{0}-C_{0}
$$

The last term in (3) implies that aggregate utility decreases with a higher primary budget balance. Then, function $f$ is multiplied by average utility $U(\bar{C})$ in order to express this decrease in utility terms which as a result causes the aggregate utility function to be homogenous. There is no explicit discounting appearing in the utility function. Nevertheless, there is implicit discounting going on through function $f$. As there is a utility "penalization" in the case of higher (lower) budget surplus, more (less) consumption in period 0 will be preferred. $^{6}$

\footnotetext{
${ }^{5}$ Another logical way is to introduce a borrowing constraint explicitly by putting limits as $B \leq \widetilde{B}(\bar{Z})$. However, in our framework where we want to understand the impact of resources on the alleviation of the borrowing constraint, this inequality should be binding. In this case, the borrowing amount will be predetermined.

${ }^{6}$ An interesting variation of the model with a slightly different utility function and discounting can be found in Appendix E.
} 
It is important to note that fiscal balance is represented as a ratio to $T$, which describes the size of the fiscal balance compared to a traditional economy and controls for the scale of the economy. Political pressure rises with $Z$ and ceases with $T$, as $T$ is collected as lump-sum taxes, whereas $Z$ is an endowment. The convexity of the $f$ function is directly related to the severity of the political pressures arising with the higher endowment shocks. If $f$ is more convex, then the government has to cope with it and increase current consumption more to decrease the disutility.

Talvi and Vegh (2005) approach the pressure to spend coming from the primary surplus through the $f$ function in two ways. First, they include it in the budget constraint as a fiscal rule. This leads to procyclicality of the current period consumption. Second, they claim that the pressure stemming from primary surplus can be modeled by including it in the utility function. In our model, we follow the second approach as our view is that in most developing countries a spending increase in favorable times is not mainly due to the fiscal rules in place, but rather is due to ad hoc government actions to ease the pressure from interest groups through unlawful means, such as rent seeking and corruption.

Maximization of the government's objective (3) given (1), (2) and (4) with respect to $B$ yields the following first-order condition:

$$
U^{\prime}\left(C_{0}\right)=U^{\prime}\left(C_{1}\right)\left[R\left(\frac{B}{\bar{Z}}\right)+\frac{B}{\bar{Z}} R^{\prime}\left(\frac{B}{\bar{Z}}\right)\right]-\frac{1}{T} f^{\prime}\left(\frac{P S_{0}}{T}\right) U(\bar{C})
$$

The Euler equation shows that consumption smoothing is disturbed and the government needs to address the disutility coming from saving the resource endowment for the next period by increasing the consumption in period 0 . Also, as interest payments increase disproportionately with the increase of the debt amount, the choice of debt amount will differ 
from the one corresponding to perfectly smoothed consumption. The last term in (5) decreases the marginal utility of consumption in period 0 and thus corresponds to the higher level of consumption in the same period. On the other hand, the term $\left[R\left(\frac{B}{\bar{Z}}\right)+\frac{B}{\bar{Z}} R^{\prime}\left(\frac{B}{\bar{Z}}\right)\right]$ leads to higher marginal utility decreasing the consumption level in period 0 .

From the first-order condition (5) it can be obtained that debt amount $B$ decreases with the increase of resource revenue $Z_{0},-1<\frac{d B}{d Z_{0}}<0 .{ }^{7}$ From (1), we obtain that current consumption increases with resource revenue but this increase is less than the resource revenue increase itself as future consumption also increases, $0<\frac{d C_{0}}{d Z_{0}}=1+\frac{d B}{d Z_{0}}<1$. In the current settings, procyclicality $\beta$ would be defined as below indicating procyclical government consumption:

$\beta=\frac{d C_{0}}{d Z_{0}} \frac{Z_{0}+T}{C_{0}}>0$

We evaluate the model driven procyclicality at $Z_{0}=Z_{1}=\bar{Z}, \bar{\beta}=\left.\frac{d C_{0}}{d Z_{0}} \frac{Z_{0}+T}{C_{0}}\right|_{Z_{0}=\bar{Z}}$. Then, as there is no investment, the whole income is consumed, $C_{0}=C_{1}=\bar{C}=\bar{Z}+T$. We assume the utility function to be $U(C)=C^{\rho}$ where $0<\rho<1$, and denote $\bar{S} \equiv \frac{\bar{Z}}{\bar{C}}$ - as the share of resource income in total income. Clearly, $0 \leq \bar{S} \leq 1$. We then obtain the following formula for $\bar{\beta}$ which depends on $\bar{S}$ :

\footnotetext{
${ }^{7}$ For detailed derivation of the model equations, please refer to Appendix C.
} 


$$
\bar{\beta} \equiv \beta(\bar{S})=\frac{\rho(1-\rho) \bar{S}(1-\bar{S})^{2}+2 \rho R^{\prime}(0)(1-\bar{S})^{2}+f^{\prime \prime}(0)}{2 \rho(1-\rho) \bar{S}(1-\bar{S})^{2}+2 \rho R^{\prime}(0)(1-\bar{S})^{2}+f^{\prime \prime}(0) \bar{S}}
$$

Equation (7) is key to describing the relationship between resource richness and government consumption procyclicality. Below, we discuss important properties of it that are consistent with observations in the previous section. To recall, the evidence suggests that there is a U-shaped relationship between recourse richness and procyclicality. It can be shown that under the current assumptions the function $\beta(\bar{S})$ has a unique internal extreme $S^{*}$, and that it is a minimum point in the interval $0 \leq \bar{S} \leq 1$, which we put as a separate proposition below. This fact gives rise to the U-shaped pattern of the function in the $[0,1]$ region.

Proposition: The function $\beta(\bar{S})$ as in (7) has a unique internal extreme in the [0,1] region and it is a minimum, given $f^{\prime \prime}(0)>0, R^{\prime}(0)>0$ and $0<\rho<1$.

Proof: see Appendix D.

Below, we provide an illustration of the pattern that emerges from the model. The model incorporates two effects stemming from resource revenues: political economy problems represented by $f^{\prime \prime}(0)$, like rent-seeking or corruption, and borrowing constraint alleviation represented by $R^{\prime}(0)$. As already mentioned, these effects are not independent of each other. Highly corrupt governments will likely face tighter borrowing constraints in the financial markets. In other words, the values of $f^{\prime \prime}(0)$ and $R^{\prime}(0)$ are most probably positively correlated. To empirically support this claim, as already mentioned earlier, there is a strong correlation between our political economy measure and borrowing constraint measure. As becomes clear in Appendix D, $A \equiv \frac{f^{\prime \prime}(0)}{\rho R^{\prime}(0)}$ plays a central role in determining the minimum 
and the shape of the curvature. Hence, in the illustration of our model we make use of this observation, and elaborate on the comparative values of $f^{\prime \prime}(0)$ and $R^{\prime}(0)$.

From Figure 7, we observe that with the increase of A the minimum of the curve moves leftwards closer to zero. Similarly, lower A is associated with the higher minimum that approaches the unit. Namely, with lower A the borrowing constraint alleviation effect dominates the political economy effect for higher levels of resource richness.

Figure 7: Illustration of the model-driven U-shape at different levels of A

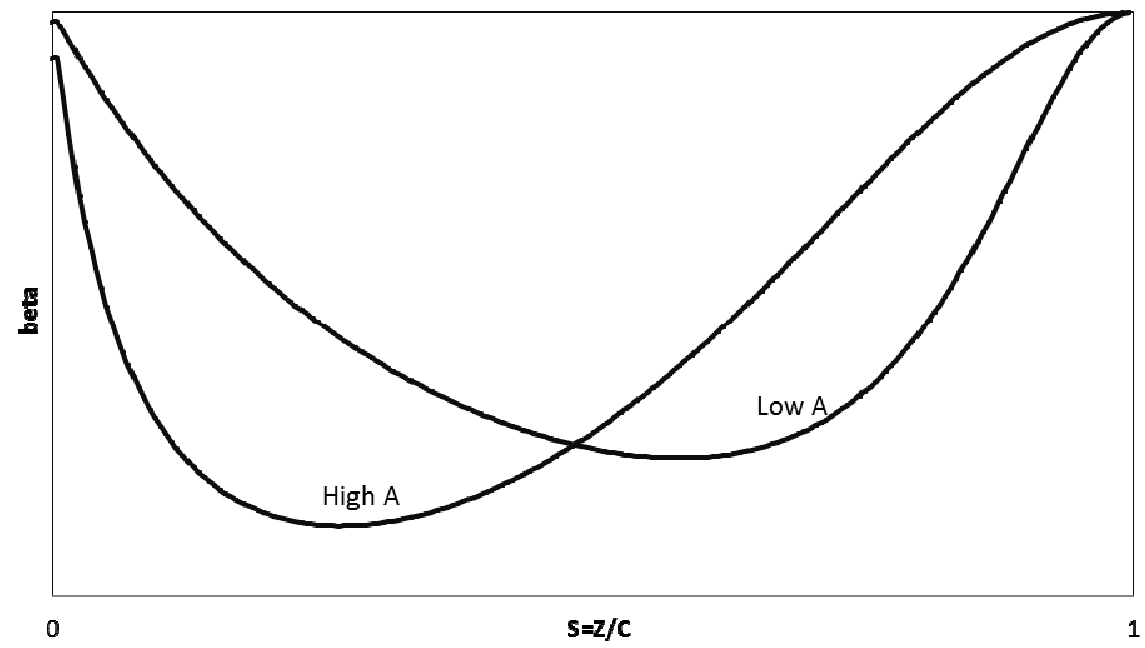

Although the ratio of $f^{\prime \prime}(0)$ and $R^{\prime}(0)$ determines the location of the minimum, the level of the curve is determined by the values of $f^{\prime \prime}(0)$ and $R^{\prime}(0)$. If we keep the ratio constant and increase the numerator and the denominator by the same multiplier then the Ucurve will move upwards without change of the minimum, as shown in Figure 8. 
Figure 8: Illustration of the model-driven U-shape for different $f^{\prime \prime}(0) \& R^{\prime}(0)$

with the same minimum

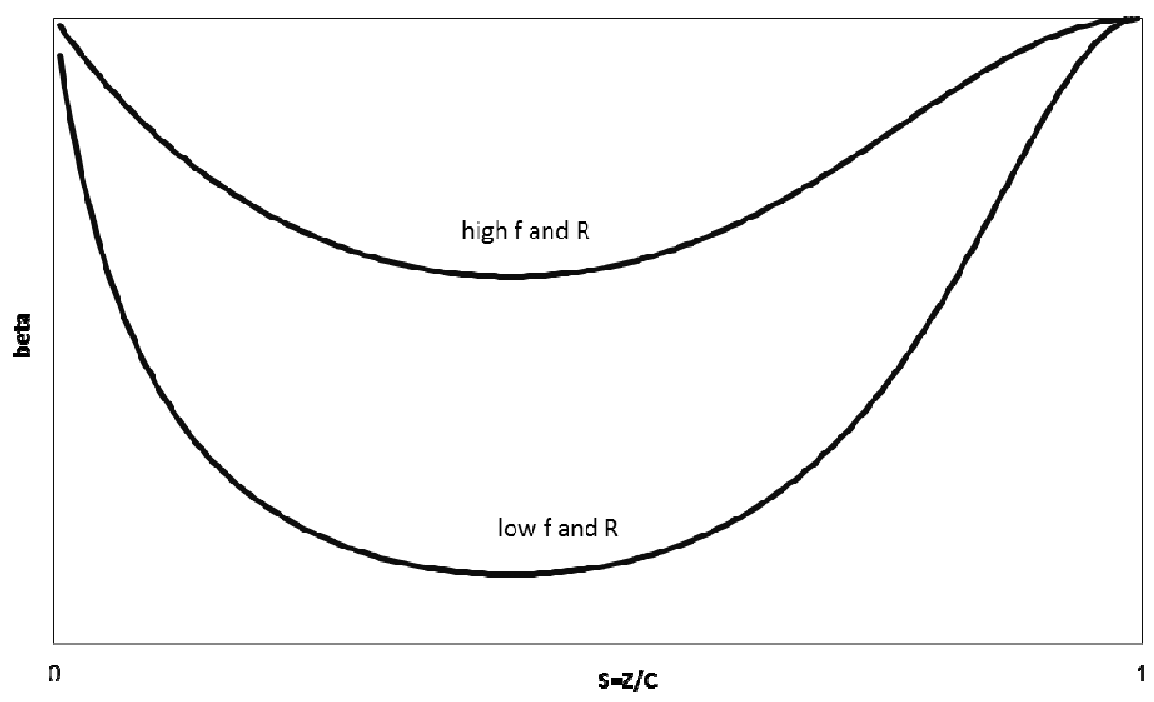

\section{Concluding remarks}

In this paper, we analyzed fiscal policy procyclicality in resource-rich countries. For developing countries, we obtained a strong U-shaped relationship between the procyclicality of capital expenditures and the resource richness measure, i.e. the mineral exports share in total merchandise exports. The U-shaped pattern was robust for different methodologies and various checks. We considered two hypotheses that in combination can generate a U-shaped impact on procyclicality: first, the political economy hypothesis, and second, the borrowing constraint hypothesis. This motivated us to build our model in Section 4. We found empirical evidence that is consistent with both hypotheses.

Interestingly, when we look at OECD countries in Table 1, i.e. Group 3 and Group 4, we see that resource richness is associated with higher procyclicality, and that it is mainly due to capital expenditures. We noted in Section 2 that OECD countries do not face borrowing constraints and have strong institutional environments. This suggests that there may be a third reason why resource richness leads to higher procyclicality. One alternative hypothesis is 
that of revenue maximization. When high resource prices are high, the return on investment in the resource sector may also be very high, and the government would want to use the opportunity in the up-cycle to maximize its revenues. This would lead to higher capital expenditures by the government and consequently to higher output in the economy. Here, the government's behavior is similar to that of a profit-maximizing firm. Although plausible, we found no empirical support for this hypothesis in the available data. We obtained a procyclicality measure for the government expenditures on mining and mineral resources, manufacturing and construction using the method similar to equation (1). However, we found no pattern of dependence between the obtained measure and the resource richness measure. The revenue maximization hypothesis, therefore, is not supported by our data.

Moreover, although we worked with multiple effects that generate a U-shaped pattern, we also explored the possibility of explaining the pattern with a single effect. Again, we found no reasonable hypothesis that can alone explain the U-shaped pattern. In this paper, we highlight the complexity of resource richness impact on fiscal policy procyclicality, and the implausibility of explaining the empirical U-shaped pattern with a single hypothesis.

We have built a model that generates the U-shaped effect combining political economy and borrowing constraint hypotheses. We have modeled political economy problems as the disutility from having a budget surplus. Under an imperfect institutional environment, high resource revenues (or budget surplus) create pressure on the government to increase spending. This leads to fiscal policy procyclicality. The borrowing constraint alleviation effect is modeled in a way that resource ownership by the government creates a wealth effect. This signals the government's long-term debt sustainability and therefore alleviating the borrowing constraint. To the best of our knowledge, this is the first paper to 
attempt to formalize the borrowing constraint alleviation hypothesis for resource-rich countries. 


\section{References}

Aizenman J., Gavin M. and Hausmann R. (2000) "Optimal Tax and Debt Policy with Endogenously Imperfect Creditworthiness", Journal of International Trade and Economic Development, vol. 9, pp. 367-395

Alesina A., Campante F. R. and Tabellini G. (2008) "Why Is Fiscal Policy Often Procyclical", Journal of the European Economic Association, vol. 6, No. 5, pp. 10061036

Aliyev I. (2011) “Understanding the Resource Impact Using Matching”, CERGE-EI Working Paper Series, No. 451

Barnett S. and Ossowski R. (2003) "Operational Aspects of Fiscal Policy in Oil Producing Countries", in Fiscal Policy Formulation and Implementation in Oil-Producing Countries, ed. by J. M. Davis, R. Ossowski, and A. Fedelino (Washington: International Monetary Fund).

Caselli F. and Cunnigham T. (2009) "Leader Behavior and the Natural Resource Curse", Oxford Economic Papers, vol. 61, pp. 628-650

Easterly W. and Rebelo S. (1993) "Fiscal Policy and Economic Growth: An Empirical Investigation", Journal of Monetary Economics, vol. 32, pp. 417-458

Eifert B., Gelb A. and Tallroth N. B. (2003) "The Political Economy of Fiscal Policy and Economic Management in Oil-Exporting Countries", in Fiscal Policy Formulation and Implementation in Oil- Producing Countries, ed. by J. M. Davis, R. Ossowski, and A. Fedelino (Washington: International Monetary Fund).

Gavin M. and Perotti R. (1997) "Fiscal Policy in Latin America", NBER Macroeconomic Annual 1997, ed. Bernanke B. and Rotemberg J., MIT Press

Hall R. E. and Jones C. I. (1999) "Why Do Some Countries Produce So Much More Output Per Worker than others?", The Quarterly Journal of Economics, vol. 114, pp. 83-116

Kaminsky G., Reinhart G. and Vegh C.A. (2004) "When It Rains, It Pours: Procyclical Capital Flows and Macroeconomic Policies”, NBER Working Paper 10780 
Karl T. L. (1999) "The Perils of the Petro-State: Reflections on the Paradox of Plenty", Journal of International Affairs, vol. 53, No.1, pp. 32-48

Kaufmann D., Kraay A. and Mastruzzi M. (2009) "Governance Matters VIII: Aggregate and Individual Governance Indicators 1996-2008”, Policy Research Working Paper 4978, The World Bank

Lane P. (2003) "The Cyclical Behavior of Fiscal Policy: Evidence from the OECD”, Journal of Public Economics, vol. 87, pp. 1661-1675

Lane P. and Tornell A. (1998) "Why Aren't Latin American Saving Rates Procyclical", Journal of Development Economics, vol. 57, pp. 185-200

Perotti R. (2007) "Fiscal Policy in Developing Countries: A Framework and Some Questions", Policy Research Working Paper 4365, The World Bank

Sachs J. D. and Warner A. M. (1997) "Natural Resource Abundance and Economic Growth", mimeo, Center for International Development and Harvard Institute for International Development, Harvard University

Sala-i-Martin X., Doppelhofer G. and Miller R.I. (2004) "Determinants of Long-term Growth: A Bayesian Averaging of Classical Estimates (BACE) Approach”, American Economic Review, vol.94, No. 4, pp.813-835

Talvi E. and Vegh C. A. (2005) "Tax Base Variability and Procyclical Fiscal Policy in Developing Countries”, Journal of Development Economics, vol. 78, pp. 156-190

Tornell A. and Lane P. (1999) "Voracity and Growth", American Economic Review, vol. 89, pp. $22-46$

Woo J. (2009) "Why Do More Polarized Countries Run More Procyclical Fiscal Policy", The Review of Economics and Statistics, vol. 91, No. 4, pp. 850-870

Zhou Y. (2009) "International Reserves and Fiscal Policy in Developing Countries”, Review of International Economics, vol. 17, No. 5, pp. 942-960 


\section{Appendix}

\section{A. Data description}

\section{Gross Domestic Product}

The United Nations Statistical Division maintains the National Statistical Database that contains the main national account aggregates for 200 countries for the period starting from 1970. It is our source for current and constant price GDP in local currencies data. It allows us to derive the measure of economic growth. Also, using current and constant price GDP data we obtain the GDP deflator. Later, this deflator is used to obtain constant price government expenditure data.

\section{Resource richness}

We use the annual mineral export and import data available from World Development Indicators 2009 since 1960 onwards. We add up the two available measures here - fuels exports and ores and metals exports as a share of total merchandise exports, and we call it the mineral export share of total merchandise exports. Using the data we derive our main measure of resource richness. We take the time series averages for 1961-2000, and obtain an average mineral export share as a share of total merchandise exports for each country (min6100). In addition, we refer to three other resource richness measures found in the literature, namely in Sachs and Warner (1997) and Sala-i-Martin, Doppelhofer and Miller (2004). These are:

- The share of exports of primary products in GNP in 1971 ( $\operatorname{sxp})$ and in $1980(\operatorname{sxp} 80)$. Primary product exports are exports of fuel and non-fuel primary products. Nonfuel primary products correspond to SITC categories $0,1,2,4$ and 68. Fuels 
correspond to SITC category 3. These categories are from the Revision 1 of the SITC. Source: Sachs and Warner (1997).

- The share of mineral production in GNP in 1971. $S N R=\frac{M 71 * 1000}{G N P D 71 * P O P 70}$, where M71 is the value of mineral production in 1971. This is calculated by Sachs and Warner (1997) from price and quantity data as: $M 71_{j}=\sum_{j=1}^{23} p_{i} \cdot m q_{i j}$. The sum is over 23 minerals.

- The fraction of GDP produced in the Mining and Quarrying sector. Data are for the year 1988 when possible, or the closest available year. Source: Sala-i-Martin et al (2004) taken from Hall and Jones (1999).

\section{Government expenditures}

Although for developing countries the government final consumption expenditures data are readily available in the national accounts tables by WDI or UN, due to measurement challenges the government investment data is missing in those tables. Government investment data for developing countries are from Easterly and Rebelo (1993) or more recent data from the Global Development Network Growth Database (GDN-GD) - Easterly database, covering the years 1970 till 2000. To analyze government expenditure data at the disaggregated level we utilize the data from the GDN-GD database. The GDN Growth Database is publicly available at: http://go.worldbank.org/ZSQKYFU6J0

\section{Borrowing constraints}

As a measure of the borrowing constraint, we refer to the ratings of government bonds issued by different rating agencies. Here, we use Foreign-Currency Government Bond 
Ratings issued by Moody's Investors Service. The ratings are as of September 2009, which "reflect the government's capacity and willingness to mobilize foreign exchange to repay its foreign-currency denominated bonds on a timely basis" (Moody's Investors Service 2006, http://www.moodys.com.br/brasil/pdf/SovGuide2006.pdf). We assign numerical values to the issued ratings between 1 and 19, 1 standing for the least constrained governments. More explicitly, $\mathrm{AAA}=1, \mathrm{AA} 1=2, \mathrm{AA} 2=3, \mathrm{AA} 3=4, \mathrm{~A} 1=5, \mathrm{~A} 2=6, \mathrm{~A} 3=7, \mathrm{BAA} 1=8, \mathrm{BAA} 2=9$, $\mathrm{BAA} 3=10, \mathrm{BA} 1=11, \mathrm{BA} 2=12, \mathrm{BA} 3=13, \mathrm{~B} 1=14, \mathrm{~B} 2=15, \mathrm{~B} 3=16, \mathrm{CAA} 1=17, \mathrm{CAA} 2=18$ and $\mathrm{CAA} 3=19$.

\section{Political economy measures}

The source of political economy indicators are Control of Corruption and Government Effectiveness measures taken from the Worldwide Governance Indicators 1996-2008 by the World Bank. Control of Corruption (CC9608) captures perceptions of the extent to which public power is exercised for private gain, including both petty and grand forms of corruption, as well as "capture" of the state by elites and private interests. Government Effectiveness (GE9608) - captures perceptions of the quality of public services, quality of the civil service and the degree of its independence from political pressures, quality of policy formulation and implementation, and credibility of the government's commitment to such policies.

\section{B. Robustness check}

To obtain an alternative procyclicality measure we run the log difference of real total government expenditures from its HP filtered level on the log-differenced real GDP gap.

$$
\ln G_{i t}-\ln G_{i t}^{H P}=\delta_{i}+\beta_{i}\left[\ln Y_{i t}-\ln Y_{i t}^{H P}\right]+\varepsilon_{i t}
$$


In the equation above, the variables denoted with HP are Hodrick-Prescott filtered series. Along with the cyclicality measure for real total government expenditures (beta_rtote_gap), we obtain an alternative cyclicality measures for real government current (beta_rcure_gap) and capital expenditures (beta_rcape_gap). As we have done to our main procyclicality measure, in Table 6 and Figure 9-11 below we show that the U-shaped pattern persists for the alternative procyclicality measure.

Table 6: OLS regressions - Alternative government expenditures procyclicality measures vs. resource richness, for non-OECD countries that have at least 20 years of government expenditure data

\begin{tabular}{|c|c|c|c|c|c|c|}
\hline & \multicolumn{2}{|c|}{ beta_rtote_gap } & \multicolumn{2}{|c|}{ beta_rcure_gap } & \multicolumn{2}{|c|}{ beta_rcape_gap } \\
\hline MIN6100 & $\begin{array}{l}-0,0012 \\
(-0,23)\end{array}$ & $\begin{array}{l}-0,0300 \\
(-1,70)^{*}\end{array}$ & $\begin{array}{l}-0,0024 \\
(-0,66)\end{array}$ & $\begin{array}{l}-0,0122 \\
(-0,91)\end{array}$ & $\begin{array}{l}-0,0024 \\
(-0,16)\end{array}$ & $\begin{array}{c}-0,1521 \\
(-3,11)^{* * *}\end{array}$ \\
\hline MIN6100_2 & - & $\begin{array}{l}0,0004 \\
(1,70)^{*}\end{array}$ & - & $\begin{array}{l}0,0001 \\
(0,76)\end{array}$ & - & $\begin{array}{c}0,0019 \\
(3,19)^{* * *}\end{array}$ \\
\hline $\begin{array}{l}\text { Adjusted } \\
\text { R_squared }\end{array}$ & 0,00 & 0,02 & 0,00 & 0,00 & 0,00 & 0,19 \\
\hline \# of obs & 38 & 38 & 37 & 37 & 36 & 36 \\
\hline
\end{tabular}

t-stats are in the brackets under coefficients. Variables MIN6100 - fuels and ores and metals exports share in total merchandise exports, MIN6100_2 - the square of $\min 6100$. 
Figure 9: Alternative total expenditures cyclicality measure in non-OECD countries - for countries that have at least 20 years of data

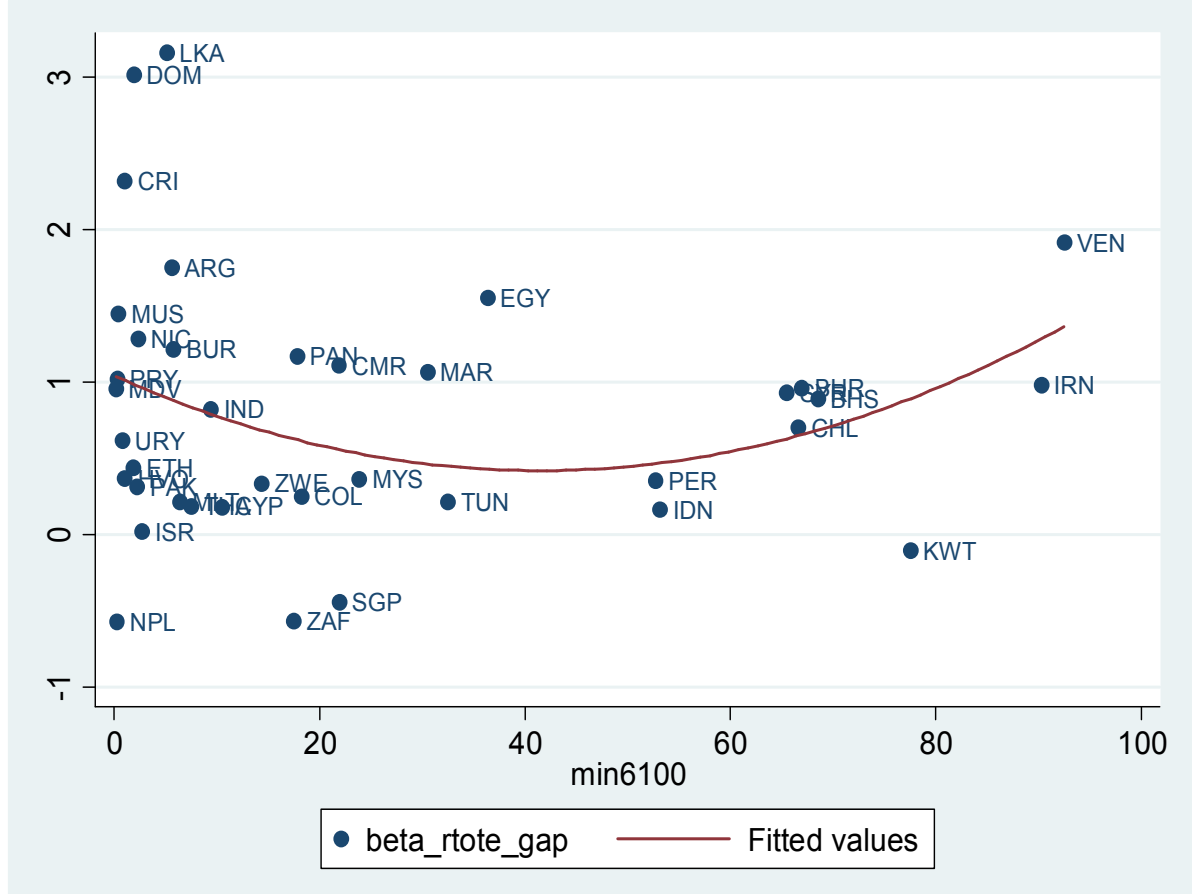

Figure 10: Alternative current expenditures cyclicality measure in nonOECD countries - for countries that have at least 20 years of data

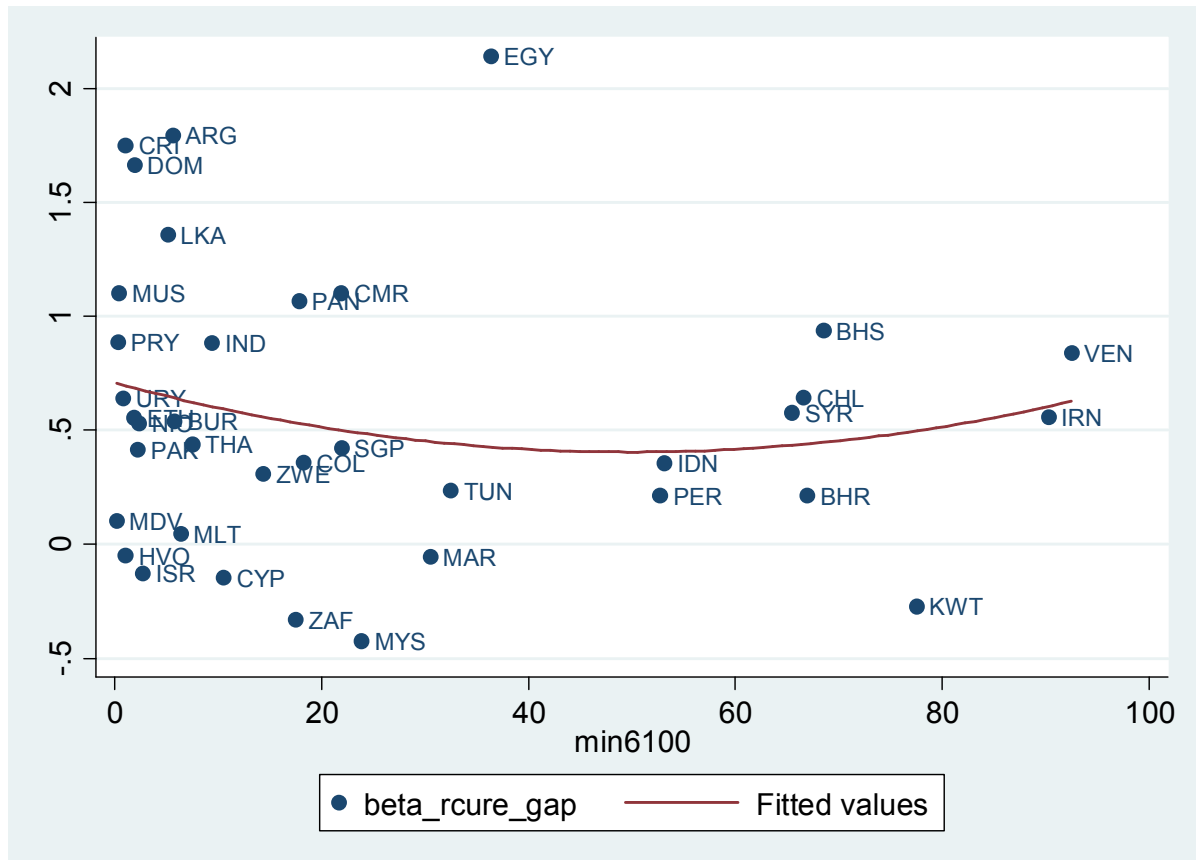


Figure 11: Alternative capital expenditures cyclicality measure in non-OECD countries - for countries that have at least 20 years of data

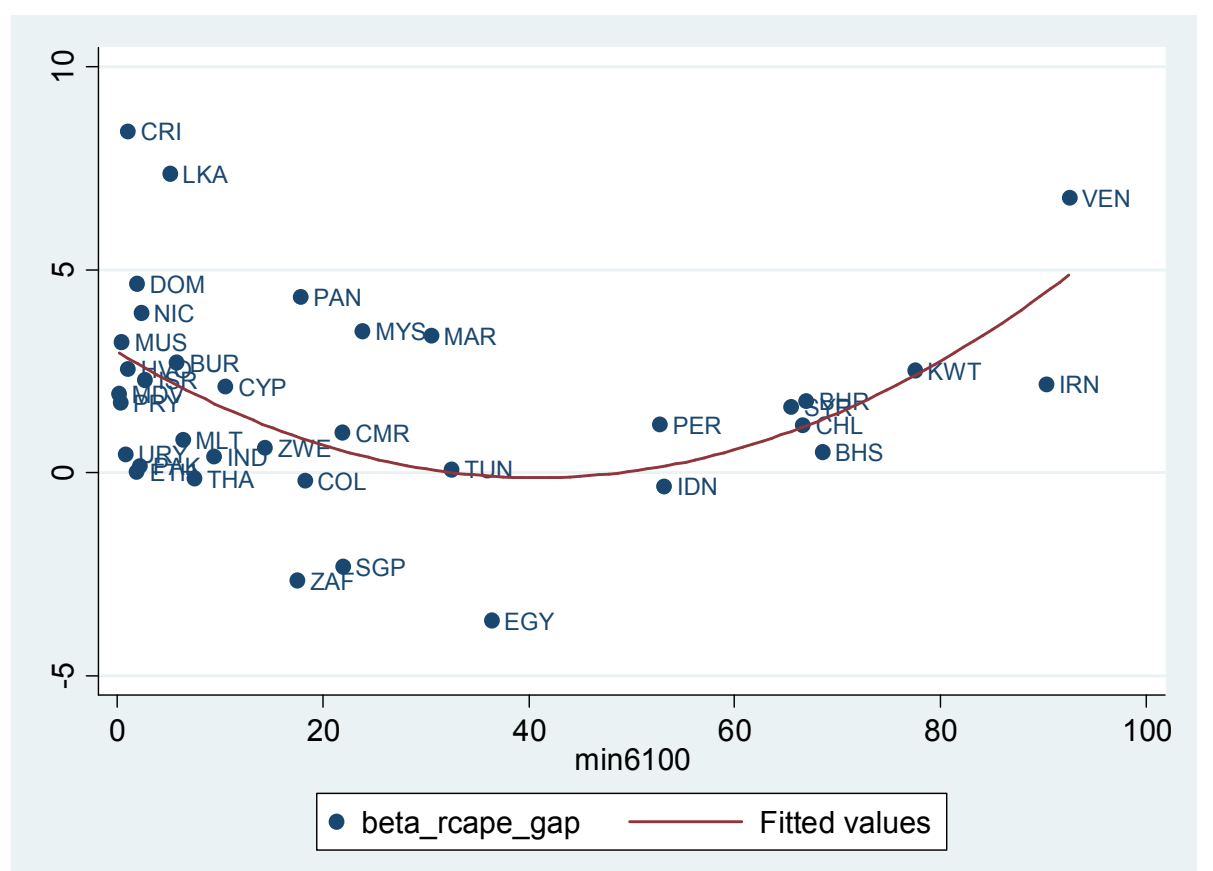

\section{Model details}

FOC for maximization problem (3) given (1), (2) and (4) is:

$U^{\prime}\left(C_{0}\right)=U^{\prime}\left(C_{1}\right)\left[R\left(\frac{B}{\bar{Z}}\right)+\frac{B}{\bar{Z}} R^{\prime}\left(\frac{B}{\bar{Z}}\right)\right]-\frac{1}{T} f^{\prime}\left(\frac{-B}{T}\right) U(\bar{C})$

Using implicit function theorem:

$\frac{d B}{d Z_{0}}=\frac{-U^{\prime \prime}\left(C_{0}\right)}{U^{\prime \prime}\left(C_{0}\right)+U^{\prime \prime}\left(C_{1}\right)\left[R\left(\frac{B}{\bar{Z}}\right)+\frac{B}{\bar{Z}} R^{\prime}\left(\frac{B}{\bar{Z}}\right)\right]^{2}-U^{\prime}\left(C_{1}\right)\left[\frac{2}{\bar{Z}} R^{\prime}\left(\frac{B}{\bar{Z}}\right)+\frac{B}{\bar{Z}^{2}} R^{\prime \prime}\left(\frac{B}{\bar{Z}}\right)\right]-\frac{1}{T^{2}} f^{\prime \prime}\left(\frac{-B}{T}\right) U(\bar{C})}<0$

From (2) we have that $\frac{d C_{0}}{d Z_{0}}=1+\frac{d B}{d Z_{0}}$. Then: 
$\frac{d C_{0}}{d Z_{0}}=\frac{U^{\prime \prime}\left(C_{1}\right)\left[R\left(\frac{B}{\bar{Z}}\right)+\frac{B}{\bar{Z}} R^{\prime}\left(\frac{B}{\bar{Z}}\right)\right]^{2}-U^{\prime}\left(C_{1}\right)\left[\frac{2}{\bar{Z}} R^{\prime}\left(\frac{B}{\bar{Z}}\right)+\frac{B}{\bar{Z}^{2}} R^{\prime \prime}\left(\frac{B}{\bar{Z}}\right)\right]-\frac{1}{T^{2}} f^{\prime \prime}\left(\frac{-B}{T}\right) U(\bar{C})}{U^{\prime \prime}\left(C_{0}\right)+U^{\prime \prime}\left(C_{1}\right)\left[R\left(\frac{B}{\bar{Z}}\right)+\frac{B}{\bar{Z}} R^{\prime}\left(\frac{B}{\bar{Z}}\right)\right]^{2}-U^{\prime}\left(C_{1}\right)\left[\frac{2}{\bar{Z}} R^{\prime}\left(\frac{B}{\bar{Z}}\right)+\frac{B}{\bar{Z}^{2}} R^{\prime \prime}\left(\frac{B}{\bar{Z}}\right)\right]-\frac{1}{T^{2}} f^{\prime \prime}\left(\frac{-B}{T}\right) U(\bar{C})}>0$

The model is evaluated at $Z_{0}=Z_{1}=\bar{Z}$. Then, $C_{0}=C_{1}=\bar{C}=\bar{Z}+T$

$1>\bar{\beta}=\left.\frac{d C_{0}}{d Z_{0}} \frac{Z_{0}+T}{C_{0}}\right|_{Z_{0}=\bar{Z}}=\frac{U^{\prime \prime}(\bar{C})-\frac{2 R^{\prime}(0)}{\bar{Z}} U^{\prime}(\bar{C})-\frac{1}{T^{2}} f^{\prime \prime}(0) U(\bar{C})}{2 U^{\prime \prime}(\bar{C})-\frac{2 R^{\prime}(0)}{\bar{Z}} U^{\prime}(\bar{C})-\frac{1}{T^{2}} f^{\prime \prime}(0) U(\bar{C})}>0$

Assuming $U(C)=C^{\rho}$ and denoting $\bar{S} \equiv \frac{\bar{Z}}{\bar{C}}$ - the share of resource income in total income, obtains:

$\bar{\beta}=\beta(\bar{S})=1-\frac{\rho(1-\rho) \bar{S}(1-\bar{S})^{2}}{2 \rho(1-\rho) \bar{S}(1-\bar{S})^{2}+2 \rho R^{\prime}(0)(1-\bar{S})^{2}+f^{\prime \prime}(0) \bar{S}}$

Solving $\frac{d \bar{\beta}}{d \bar{S}}=0$ obtains the internal minimum point.

$\frac{d \bar{\beta}}{d \bar{S}}=\frac{2 \rho(1-\rho)\left[f^{\prime \prime}(0) \bar{S}^{2}(1-\bar{S})-\rho R^{\prime}(0)(1-\bar{S})^{4}\right]}{\left.2 \rho(1-\rho) \bar{S}(1-\bar{S})^{2}+2 \rho R^{\prime}(0)(1-\bar{S})^{2}+f^{\prime \prime}(0) \bar{S}\right]^{2}}=0$

\section{Proof of the proposition}

First, we need to show that for $\bar{S} \in[0,1]$ there exists an internal minimum. In other words, we should find at least one solution for $\left.\frac{d \bar{\beta}}{d \bar{S}}\right|_{\bar{S}=S^{*}}=0$ which will be a local minimum. To do so, we take the first derivative of the function $\beta(\bar{S})$ and equalize it to zero. It yields: 
$A \cdot S^{* 2}-(1-S *)^{3}=0$

where for simplicity in notation $A \equiv \frac{f^{\prime \prime}(0)}{\rho R^{\prime}(0)} \geq 0$ and $0 \leq S^{*} \leq 1$.

(C.1) can be written as:

$S^{*^{3}}+(A-3) S *^{2}+3 S^{*}-1=0$

From the properties of the cubic equation we know that it has at least one real root. Using the implicit function formula we show that in the interval between 0 and $1, \mathrm{~S}^{*}$ decreases with A:

$$
\frac{d S^{*}}{d A}=-\frac{S^{* 2}}{3 S^{* 2}+2(A-3) S^{*}+3}<0
$$

To explore further we will use graphical analysis. Figure 12 below plots $\mathrm{S}^{*}$ and A relationship without any restrictions, $\mathrm{S}^{*}$ being the $\mathrm{x}$-axis and A being the $\mathrm{y}$-axis.

Figure 12: Relationship between A (y-axis) and $\mathrm{S}^{*}$ (x-axis)

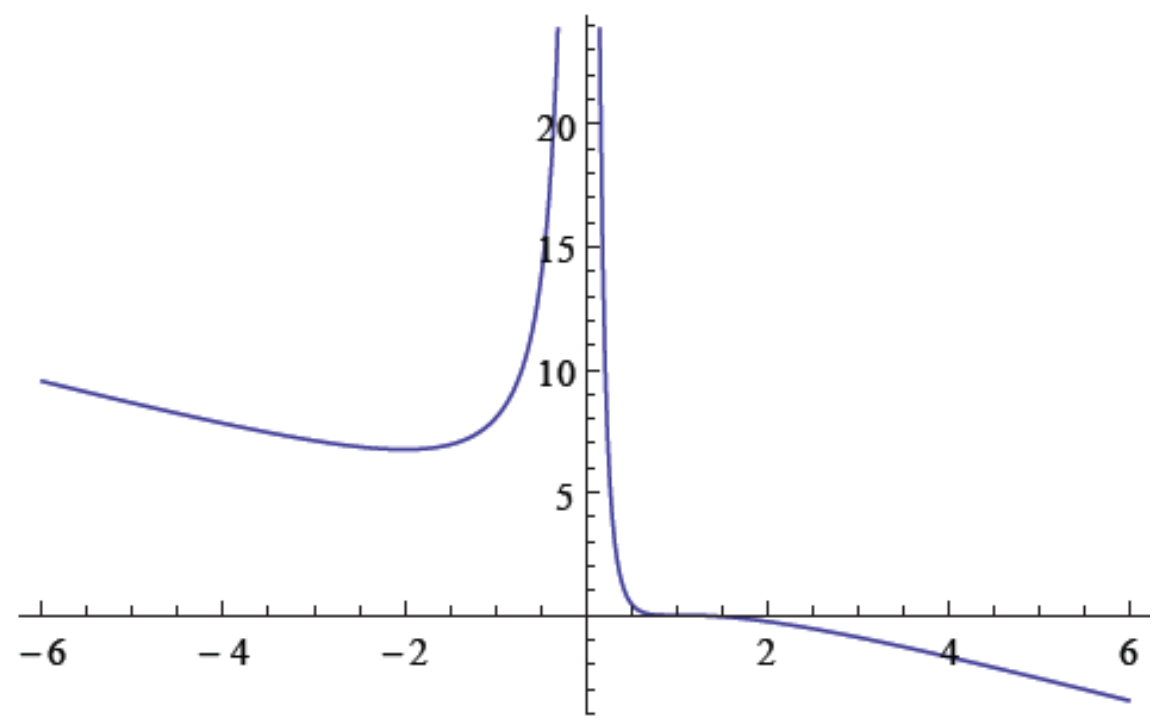


From the graphical analysis, as well as from the analysis of the determinant of (C.2), we have the following results:

1) If $0 \leq A<\frac{27}{4}$, then there is a unique $S^{*} \in(0,1]$ solving (C.2).

2) If $A>\frac{27}{4}$, then there are three $\mathrm{S}^{*}$ solving (C.2). One of them is in the interval $(0,1]$ and the other two are negative.

3) If $A=\frac{27}{4}$, then there are two $\mathrm{S}^{*}$ solving (C.2); One of them is in the interval $(0,1]$ and the other is negative.

4) $A<0$ is not attainable with the current settings.

From the results above it is clear that there is always $\mathrm{S}^{*}$ for any $\mathrm{A}>0$ solving (C.2) and it is unique in the interval of our interest(0,1]. Figure 13 exhibits this fact clearly by zooming in Figure 12 for the $(0,1]$ interval. This can be interpreted as such that for any values of $f^{\prime \prime}(0)$ and $R^{\prime}(0)$ the function $\beta(\bar{S})$ as in (7) has unique extreme point. 
Figure 13: Relationship between A (y-axis) and minimum $\mathrm{S}^{*}$ (x-axis) for $S^{*} \in(0,1]$

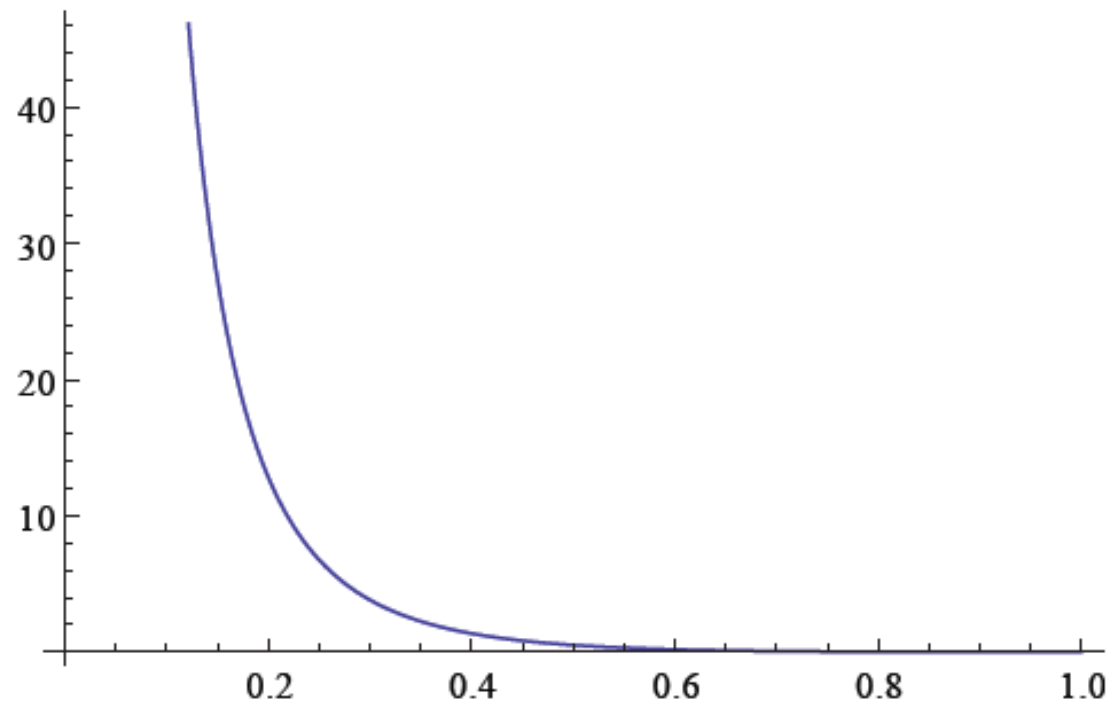

To show that it is a minimum we pursue a simple numerical check. Here, if we show one example that this is a minimum then it would be sufficient to claim for the general case. Let us assume $f^{\prime \prime}(0)=0.01, \quad R^{\prime}(0)=0.01 \quad$ and $\rho=0.9$. Then, $S^{*}=0.42$ and $\beta\left(S^{*}\right)=0.64368$. Any values of $\mathrm{S}^{*}$ different from 0.42 should yield higher $\beta$. In our case, $\beta(0.40)=0.64395$ and $\beta(0.44)=0.64398$ that are higher than $\beta(0.42)$. Hence, $\mathrm{S}^{*}$ is the minimum.

\section{E. Model variation}

Different from (3) we now examine the aggregate utility function in the following form subject to (1) and (2):

$U\left(C_{0}\right)+U\left(C_{1}\right)-f\left(\frac{P S_{0}}{T}\right) U\left(C_{1}\right)=U\left(C_{0}\right)+\left[1-f\left(\frac{P S_{0}}{T}\right)\right] U\left(C_{1}\right)$ 
The term $\left[1-f\left(\frac{P S_{0}}{T}\right)\right]$ can be viewed as a discounting. In case of no budget surplus the discounting term becomes 1 . The necessary assumption here is that $1-f\left(\frac{P S_{0}}{T}\right)>0$ to treat it as a discounting term. This is similar to Caselli and Cunugham (2009) as they view it as a probability of surviving for the next period.

It yields the Euler equation as follows:

$U^{\prime}\left(C_{0}\right)=U^{\prime}\left(C_{1}\right)\left[R\left(\frac{B}{\bar{Z}}\right)+\frac{B}{\bar{Z}} R^{\prime}\left(\frac{B}{\bar{Z}}\right)\right]\left[1-f\left(\frac{P S_{0}}{T}\right)\right]-\frac{1}{T} f^{\prime}\left(\frac{P S_{0}}{T}\right) U\left(C_{1}\right)$

Using the implicit function theorem:

$\frac{d B}{d Z_{0}}=\frac{-U^{\prime \prime}\left(C_{0}\right)}{U^{\prime \prime}\left(C_{0}\right)+\left[1-f\left(\frac{P S_{0}}{T}\right)\right]\left\{U^{\prime \prime}\left(C_{1}\right)\left[R\left(\frac{B}{\bar{Z}}\right)+\frac{B}{\bar{Z}} R^{\prime}\left(\frac{B}{\bar{Z}}\right)\right]^{2}-U^{\prime}\left(C_{1}\right)\left[\frac{2}{\bar{Z}} R^{\prime}\left(\frac{B}{\bar{Z}}\right)+\frac{B}{\bar{Z}^{2}} R^{\prime \prime}\left(\frac{B}{\bar{Z}}\right)\right]\right\}-\frac{1}{T^{2}} f^{\prime \prime}\left(\frac{P S_{0}}{T}\right) U\left(C_{1}\right)}<0$

Clearly, $-1<\frac{d B}{d Z_{0}}<0$. Also, we have that $\frac{d C_{0}}{d Z_{0}}=1+\frac{d B}{d Z_{0}}$. Then:

$\frac{d C_{0}}{d Z_{0}}=\frac{\left[1-f\left(\frac{P S_{0}}{T}\right)\right]\left\{U^{\prime \prime}\left(C_{1}\right)\left[R\left(\frac{B}{\bar{Z}}\right)+\frac{B}{\bar{Z}} R^{\prime}\left(\frac{B}{\bar{Z}}\right)\right]^{2}-U^{\prime}\left(C_{1}\right)\left[\frac{2}{\bar{Z}} R^{\prime}\left(\frac{B}{\bar{Z}}\right)+\frac{B}{\bar{Z}^{2}} R^{\prime \prime}\left(\frac{B}{\bar{Z}}\right)\right]\right\}-\frac{1}{T^{2}} f^{\prime \prime}\left(\frac{P S_{0}}{T}\right) U\left(C_{1}\right)}{U^{\prime \prime}\left(C_{0}\right)+\left[1-f\left(\frac{P S_{0}}{T}\right)\right]\left\{U^{\prime \prime}\left(C_{1}\right)\left[R\left(\frac{B}{\bar{Z}}\right)+\frac{B}{\bar{Z}} R^{\prime}\left(\frac{B}{\bar{Z}}\right)\right]^{2}-U^{\prime}\left(C_{1}\right)\left[\frac{2}{\bar{Z}} R^{\prime}\left(\frac{B}{\bar{Z}}\right)+\frac{B}{\bar{Z}^{2}} R^{\prime \prime}\left(\frac{B}{\bar{Z}}\right)\right]\right\}-\frac{1}{T^{2}} f^{\prime \prime}\left(\frac{P S_{0}}{T}\right) U\left(C_{1}\right)}>0$

The equation above is evaluated at $Z_{0}=Z_{1}=\bar{Z}$. Then, $C_{0}=C_{1}=\bar{C}=\bar{Z}+T$. We obtain: 
$1>\bar{\beta}=\left.\frac{d C_{0}}{d Z_{0}} \frac{Z_{0}+T}{C_{0}}\right|_{Z_{0}=\bar{Z}}=\frac{U^{\prime \prime}(\bar{C})-\frac{2 R^{\prime}(0)}{\bar{Z}} U^{\prime}(\bar{C})-\frac{1}{T^{2}} f^{\prime \prime}(0) U(\bar{C})}{2 U^{\prime \prime}(\bar{C})-\frac{2 R^{\prime}(0)}{\bar{Z}} U^{\prime}(\bar{C})-\frac{1}{T^{2}} f^{\prime \prime}(0) U(\bar{C})}>0$

The result is the same as for the model in the text. Hence, the consequential analysis applies, yielding a U-shaped relationship between procyclicality and resource richness. 
Working Paper Series

ISSN 1211-3298

Registration No. (Ministry of Culture): E 19443

Individual researchers, as well as the on-line and printed versions of the CERGE-EI Working Papers (including their dissemination) were supported from the following institutional grants:

- Economic Impact of European Integration on the Czech Republic [Ekonomické dopady evropské integrace na ČR], No. MSM0021620846, (2005-2011);

Specific research support and/or other grants the researchers/publications benefited from are acknowledged at the beginning of the Paper.

(c) Ilkin Aliyev, 2012

All rights reserved. No part of this publication may be reproduced, stored in a retrieval system or transmitted in any form or by any means, electronic, mechanical or photocopying, recording, or otherwise without the prior permission of the publisher.

Published by

Charles University in Prague, Center for Economic Research and Graduate Education (CERGE) and

Economics Institute ASCR, v. v. i. (EI)

CERGE-El, Politických vězňů 7, 11121 Prague 1, tel.: +420 224005 153, Czech Republic.

Printed by CERGE-EI, Prague

Subscription: CERGE-El homepage: http://www.cerge-ei.cz

Phone: + 420224005153

Email: office@cerge-ei.cz

Web: http://www.cerge-ei.cz

Editor: Michal Kejak

Editorial board: Jan Kmenta, Randall Filer, Petr Zemčík

The paper is available online at http://www.cerge-ei.cz/publications/working_papers/.

ISBN 978-80-7343-267-6 (Univerzita Karlova. Centrum pro ekonomický výzkum a doktorské studium)

ISBN 978-80-7344-259-0 (Národohospodářský ústav AV ČR, v. v. i.) 
CERGE-EI

P.O.BOX 882

Politických vězňů 7

11121 Praha 1

Czech Republic http://www.cerge-ei.cz 